ISSN (print): 1698-6180. ISSN (online): 1886-7995

www.ucm.es/info/estratig/journal.htm

Journal of Iberian Geology 37 (2) 2011: 231-246

doi: 10.5209/rev_JIGE.2011.v37.n2.10

\title{
The response of benthic foraminifera to pollution and environmental stress in Ria de Aveiro (N Portugal)
}

\author{
La respuesta de los foraminíferos bentónicos a la contaminación y \\ el estrés ambiental en la Ría de Aveiro ( $\mathrm{N}$ de Portugal)
}

\author{
V. Martins ${ }^{1,2, *}$, C. Yamashita 3 , S.H.M. Sousa ${ }^{3}$, P. Martins ${ }^{4}$, L.L.M. Laut ${ }^{5}$, R.C.L. Figueira 3 , M.M. \\ Mahiques $^{3}$, E. Ferreira da Silva ${ }^{1}$, J.M. Alveirinho Dias ${ }^{6}$, F. Rocha ${ }^{1}$ \\ ${ }^{1}$ GeoBioTec Research Centre, University of Aveiro, Dpt. of Geosciences, Campus de Santiago, 3810-193 Aveiro, Portugal \\ (virginia.martins@ua.pt; tavares.rocha@ua.pt; eafsilva@ua.p) \\ ${ }^{2}$ CESAM, University of Aveiro, Department of Geosciences, Aveiro, Portugal \\ ${ }^{3}$ Oceanographic Institute, São Paulo University, Brazil \\ (cintia.yamashita@usp.br;smsousa@usp.br;rfigueira@usp.br;mahiques@usp.br) \\ ${ }^{4}$ University of Aveiro, Geosciences Department, Portugal \\ (paulamartins@ua.pt) \\ ${ }^{5}$ Natural Science Department, Institute of Biosciences, Federal University of the State of Rio de Janeiro - UNIRIO, Brazil \\ (lazarolaut@hotmail.com) \\ ${ }^{6}$ Algarve University, Campus de Gambelas, Faro,Portugal (jdias@ualg.pt) \\ *corresponding author
}

Received: 14/03/11 / Accepted: 19/10/11

\begin{abstract}
This work evaluates the quality of the sediment in Ria de Aveiro, a coastal lagoon located at $\mathrm{N}$ of Portugal that is under strong anthropic influence, and the effects of the contamination on benthic foraminifera. The initial approach for measuring pollution was done through the load pollution index (LPI), based on $\mathrm{As}, \mathrm{Cd}, \mathrm{Cr}, \mathrm{Cu}, \mathrm{Ni}, \mathrm{Pb}$ and $\mathrm{Zn}$ concentrations, and determined by total digestion of the sediments (TDS). This information was complemented by conducting a metal fractionation technique (sequential chemical extraction - SCE) in some of the most contaminated samples in order to define the relevance of different metal bearingphases (exchangeable cations adsorbed by clay and co-precipitated with carbonates, absorbed by organic matter and retained in the mineralogical phase) and to evaluate the toxic heavy metal availability. Multivariable statistical analyses were carried out taking into consideration the geochemical results, as well as the biotic (percentage of species/groups of species; foraminifer abundance and diversity) and abiotic variables, such as sediment content in mud, total organic carbon (TOC) and Eh.

SCE results show that most of the element concentration in the sediments is retained in the resistant mineralogical phase. However, the higher bioavailability of some toxic elements, such as $\mathrm{As}, \mathrm{Cd}, \mathrm{Cu}, \mathrm{Hg}, \mathrm{Ni}, \mathrm{Pb}$ and $\mathrm{Zn}$, found in Laranjo Bay, Aveiro City, Aveiro Harbours and Espinheiro Channel, have a generic negative impact on benthic foraminifera of the Aveiro lagoon. Differential sensitivity of benthic foraminifera to high concentrations of heavy metals may exist. Quinqueloculina seminulum, for instance, seems to be more tolerant to higher bioavailable concentrations of $\mathrm{Pb}$ and $\mathrm{Cu}$ than Ammonia tepida or Haynesina germanica. Both
\end{abstract}


species were previously considered to be the most heavy metal-tolerant foraminifer species.

This study confirmed the use of benthic foraminifera as an important tool for the evaluation of the environmental quality of an ecosystem and for monitoring and restoring it.

Keywords: toxic elements; geochemical analysis; benthic foraminifera; lagoon system, Ria de Aveiro, N Portugal

Resumen

Este trabajo evalúa la calidad de los sedimentos en la Ría de Aveiro, una laguna costera situada en el N de Portugal, bajo la influencia antrópica fuerte, y los efectos de la contaminación en los foraminíferos bentónicos. El planteamiento inicial para la medición de la contaminación se realiza a través del índice de carga de contaminación (LPI) con base en concentraciones de As, Cd, Cr, $\mathrm{Cu}, \mathrm{Ni}, \mathrm{Pb}$ y $\mathrm{Zn}$, determinadas por la digestión total de los sedimentos (TDS). Esta información se complementó con una técnica de fraccionamiento de metal (extracción química secuencial - SCE) en algunas de las muestras más contaminadas, con el fin de definir la relevancia de los distintos metales y de las fases (cationes intercambiables adsorbidos por la arcilla y el precipitado con carbonatos, absorbida por materia orgánica y retenido en la fase mineralógica) y para evaluar la disponibilidad de metales pesados tóxicos. Multivariado análisis estadísticos se llevaron a cabo teniendo en cuenta los resultados geoquímicos y también las variables bióticas (porcentaje de especies/grupos de especies, abundancia de foraminíferos y la diversidad) y otras variables abióticas, como el contenido de los sedimentos en barro, el carbono orgánico total (COT) y el Eh .

Los resultados de SCE muestran que la mayor parte de las concentraciones de los elementos en los sedimentos se retiene en la fase mineralógica resistente. Sin embargo biodisponibilidad superior de algunos elementos tóxicos, tales como $\mathrm{As}, \mathrm{Cd}, \mathrm{Cu}, \mathrm{Hg}, \mathrm{Ni}, \mathrm{Pb}$ y Zn, que se encuentra en lo Largo do Laranjo, en la ciudad de Aveiro, en el puertos de Aveiro and en el Canal de Espinheiro, tienen un impacto negativo genérico en el foraminíferos bentónicos de la laguna de Aveiro. Sin embargo, la sensibilidad diferencial de los foraminíferos bentónicos a altas concentraciones de metales pesados puede existir. Quinqueloculina seminulum, por ejemplo, parece ser más tolerante a las altas concentraciones biodisponibles de $\mathrm{Pb}$ y $\mathrm{Cu}$, de que Ammonia tepida o Haynesina germanica. Antes se consideraban que ambas especies eran los foraminíferos más tolerantes a la contaminación por metales pesados.

Este estudio confirmó el uso de los foraminíferos bentónicos como una importante herramienta para la evaluación de la calidad ambiental de los ecosistemas y también para el seguimiento y la restauración.

Palabras clave: elementos tóxicos, análisis geoquímicos, foraminíferos bentónicos, sistema lagunar, Ría de Aveiro, N de Portugal

\section{Introduction}

In the past decades, the degradation of aquatic environments has become a topic of increasing concern among the public. In northern Portugal, the natural features of Ria de Aveiro have been intensely modified, mainly as a result of urbanization and industrial development.

More than 300,000 inhabitants live around the lagoon and its channels. This high concentration of people in such a small area has brought up several environmental problems and contributed to the degradation of the lagoon's water quality. Industrial and agricultural activities are intense, stressing the local resources, and land development is on the rise around Ria de Aveiro. The main vulnerable areas of the lagoon, from a water quality point of view, seem to be the far end of the main channels, where a low dissolved oxygen concentration is observed (Lopes et al., 2005) and where eutrophication can occur (Lopes and Silva, 2006). These areas are also affected by chemical contaminants related to anthropic actions. In Estarreja Channel, for example, industrial and urban effluents have been discharged, for several years, by the industrial plant north of the village of Estarreja, the so-called 'Complexo Químico de Estarreja’ (e.g., Pereira et al., 2009, 2006, 2005, 1998a, b, 1995; Válega et al., 2008; Coelho et al.,
2006, 2005; Ramalhosa et al., 2006; Monterroso et al., 2003; Abreu et al., 2000).

Benthic foraminifera have exceptional utility as bioindicators of coastal contamination. The impact of pollution, mainly by heavy metals and organic matter, on benthic foraminifera has been the goal of an increasing number of research lines (e.g., Frontalini et al., 2011; Martins et al., 2010; Carnahan et al., 2009; Romano et al., 2008; Burone et al., 2007, 2006; Armynot du Châtelet et al., 2003, Yanko et al., 1999, 1998; Alve, 1995, 1991). Most of these works evaluate the degree of stress caused by pollutants in foraminifera and are based on the total sedimentary elemental concentration of heavy metals. In general, the bioavailability of pollutants is neglected in most of these works. According to Neff (2002), bioavailability is the extent to which a chemical can be absorbed or adsorbed by a living organism through active (biological) or passive (physical or chemical) processes.

The main goals of this study are identifying heavy metal contamination patches caused by anthropic activities in the sediments of the Ria de Aveiro channels and evaluating the effects of higher bioavailable concentrations of heavy metals (determined by sequential chemical extractions using ICP-MS) on benthic foraminifera. 


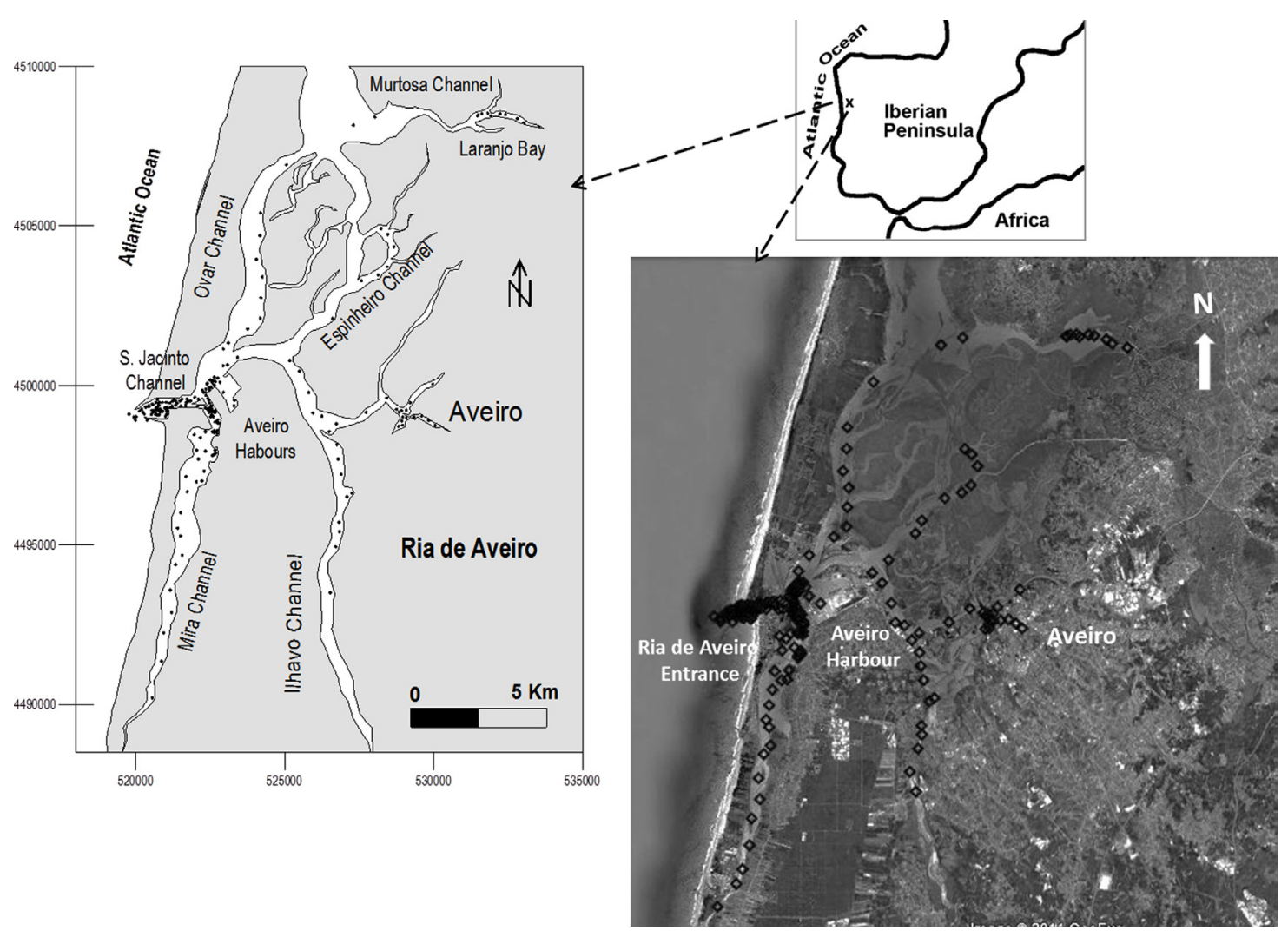

Fig. 1. - Ria de Aveiro location and sampling sites.

Fig. 1. - Ría de Aveiro: situación y sitios de muestreo.

\section{Study area}

Ria de Aveiro is a lagoon located on the NW coast of the Iberian Peninsula $\left(40^{\circ} 38^{\prime} \mathrm{N}, 8^{\circ} 45^{\prime} \mathrm{W}\right)$ and connected with the Atlantic Ocean through a single artificial entrance opened in 1808 (Fig. 1). This lagoon covers an area of $83 \mathrm{~km}^{2}$ at high tide (spring tide) and $66 \mathrm{~km}^{2}$ at low tide (Dias and Lopes, 2006). It has a very irregular and complex geometry, comprised of long and narrow channels, with a high longitudinal development organized by successive ramifications from the mouth as an arborescent network system. Ria de Aveiro has four main channels - S. Jacinto/Ovar, Ílhavo, Mira and Espinheiro and is composed of a complex network of branches, bays and narrow channels. The deepest areas of the lagoon are confined to the inlet channel and to small areas close to the lagoon's mouth, at its western boundary, where the depths may reach values in the order of $30 \mathrm{~m}$. Elsewhere, the depths are, in general, no greater than $3 \mathrm{~m}$, and most frequently close to $1 \mathrm{~m}$, namely at the upper lagoonal area (Lopes et al., 2006).

According to Dias et al. (1999), the lagoon hydrographical regime is characterized by several periodic timescales, the most important of which are the tidal period (semi-diurnal) and one half of the lunar month (spring-neap cycle). Tidal currents are the main force behind water circulation in the Aveiro lagoon. Tides are semidiurnal and are present in the entire lagoon. The tidal current velocities near the entrance can be higher than 2 $\mathrm{m} / \mathrm{s}$ (Vaz and Dias, 2008; Dias et al., 2000), but they are weak in many of the innermost small canals and mudflats. Winds affect both the hydro-dynamical regime and the mixing processes in the lagoon by generating surface shear stress and waves (Lopes et al., 2006). The lagoon receives freshwater supplied by several rivers and riverine bodies. The main rivers are the Vouga $\left(\sim 50 \mathrm{~m}^{3} / \mathrm{s}\right.$ average discharge) and the Antuã ( $\left.\sim \mathrm{m}^{3} / \mathrm{s}\right)$ (Moreira et al., 1993). The river influence is higher in the upper and inner parts of the lagoon (Vaz and Dias, 2008).

\section{Materials and methods}

\subsection{Sampling and sample preparation}

A total of 215 grab-samples collected in 2006/07 in the Ria de Aveiro channels using a boat (ZOE I) were analyzed for grain size, heavy metals and microfauna (benthic foraminifera). During the sampling campaigns, the depth was measured with the boat's sonar and the sites were located with GPS. The surface sediment samples were collected with an adapted Petit Ponar Grab (opening at both extremities). Only the top $\sim 5 \mathrm{~cm}$ of sediment were 
retained for analysis. Sediment splits were taken at each site for textural, geochemical and microfaunal (benthic foraminifera) analyses. The sediments sampled for geochemical analysis were immediately frozen on board. The samples collected for foraminifera studies were stored in buffered ethanol stained with Rose Bengal (2 g of Rose Bengal in 1,000 $\mathrm{ml}$ of alcohol). Rose Bengal was used to differentiate between living and dead foraminifera (e.g., Murray, 1991).

\subsection{Methods}

\section{Field parameters}

Some environmental parameters, such as temperature, salinity/conductivity, $\mathrm{pH}$ and $\mathrm{Eh}$, were measured in bottom water and sediment. Once in the laboratory, the sediment samples for textural and geochemical analysis were dried to constant weight in an oven for about $72 \mathrm{~h}$, at $45^{\circ} \mathrm{C}$, and stored for subsequent analysis.

\section{Grain Size Analysis}

For the grain size analysis, the dried sediment samples were homogenized and a portion of about 150-250 $\mathrm{g}$ was analyzed. The fine fraction was separated from the sand fraction by wet sieving using a $63 \mu \mathrm{m}$ screen. The sediment fraction coarser than $63 \mu \mathrm{m}$ was dry sieved through a battery of sieves spaced at 1 phi (ø) unit.

\section{Chemical Analysis}

For the geochemical analysis, a split of the sediment fraction finer than $2,000 \mu \mathrm{m}$ of each sample was milled. The concentrations of 41 chemical elements were determined at ACME Analytical Laboratories, Canada. The analysis was done by ICP-MS analysis after the total digestion of sediment (TDS) with acid $\left(\mathrm{HClO}_{4}-\mathrm{HNO}_{3}-\right.$ $\mathrm{HCl}-\mathrm{HF}$ ). Concentrations of Al, Fe, $\mathrm{P}, \mathrm{Zn}, \mathrm{Pb}, \mathrm{Cr}, \mathrm{Cu}, \mathrm{As}$, $\mathrm{Ni}$ and $\mathrm{Cd}$ were analysed in this work.

Additionally, 17 samples (Laranjo Bay - Lar1, Lar3, Lar5, Lar6; Aveiro Town - C14; Espinheiro Channel CC3, CC5, CC6, CC17; Ílhavo Channel - CI5, CI10; lagoon mouth - EM 22; Aveiro Harbours - Lota1, Lota3, CCom1 and CCom2) were chosen in different lagoonal areas for their high heavy metal concentration and submitted to sequential chemical extractions (SCE) in order to assess the element concentration retained by a specific sediment phase or range of phases. SCE were performed using the following procedure: Step $1-1.0 \mathrm{~g}$ of sample was leached with $10 \mathrm{ml}$ of ammonium-acetate-EDTA solution ( $\mathrm{pH} 4.65$ ) for $1 \mathrm{~h}$, followed by analysis by ICP-MS (exchangeable cations adsorbed by clay and elements coprecipitated with carbonates); Step 2 - the residue was leached with $10 \mathrm{ml}$ of $0.1 \mathrm{M}$ sodium pyrophosphate $(\mathrm{Na}-$ ${ }_{3} \mathrm{P}_{3} \mathrm{O}_{7}$ ) for $1 \mathrm{~h}$ (adsorbed by organic matter - humic and fulvic compounds). The element concentrations in the other phases were calculated as the difference between the total concentration and the sum of the two steps (1 and 2).

Total organic carbon (TOC) was determined in a portion of bulk sediment from each sample. Samples were dried at $105^{\circ} \mathrm{C}$ for $8 \mathrm{~h}$. About $5 \mathrm{~g}$ of dry sediment were submitted to loss-on-ignition (LOI) at $450{ }^{\circ} \mathrm{C}$ for $8 \mathrm{~h}(\mathrm{Ol}-$ iver et al., 2001). TOC values are reported as percentages of dry weight.

\section{Foraminiferal studies}

The samples were washed over a sieve of $63 \mu \mathrm{m}$ mesh. As foraminifera are rare in the dry sediment fraction $>500 \mu \mathrm{m}$, in the studied area, the sediments fraction 63$500 \mu \mathrm{m}$ was used to determine the abundance of benthic foraminifera, expressing the number of tests per gram of dry bulk sediment, and also to study the composition of living assemblages. Foraminiferal tests having rose Bengal stained interiors and containing protoplasm were considered living at the time of the collection (e.g. Horton et al., 1999; Murray and Alve, 1999). For the study of benthic foraminifer's assemblages, samples were split until it was ideally possible to obtain 300 living specimens. In samples with low number of foraminifera the minimum number of 100 living specimens was used in statistical analysis (Fatela and Taborda, 2002). The number of species per sample (S) and Shannon-index $(\mathrm{H})$ values Shannon (1948); $H=-\Sigma$ pi.ln(pi), where pi is the proportion of each species] were employed to identify changes in the diversity of species. Equitability $(E)[E=\ln (S) ; S$ is the number of species per sample] was also analysed. The proportion of living organisms considering the total assemblage also was determined.

\section{Data Analysis}

The load pollution index (LPI) defined by Tomlinson et al. (1980) was used in order to estimate the overall pollution level of the samples. This index is based on concentrations determined by TDS through the equation:

$$
\mathrm{LPI}=\sum_{n=1}^{n-x} \mathrm{EFn}^{1 / \mathrm{x}}
$$

where $\mathrm{EF}$ is the enrichment factor defined as $\mathrm{EF}=\mathrm{C}_{\mathrm{n}} / \mathrm{B}_{\mathrm{n}}$; $\mathrm{C}_{n}$ represents the measured concentration of the metal $n$ and $\mathrm{B}_{\mathrm{n}}$ is the background concentration of the metal $\mathrm{n}$; $\mathrm{x}$ is the number of metals considered. The $\mathrm{x}$ value in this study is 7 and it includes the elements $\mathrm{As}, \mathrm{Cd}, \mathrm{Cr}, \mathrm{Cu}$, $\mathrm{Ni}, \mathrm{Pb}$ and $\mathrm{Zn}$. Since the background values of these met- 

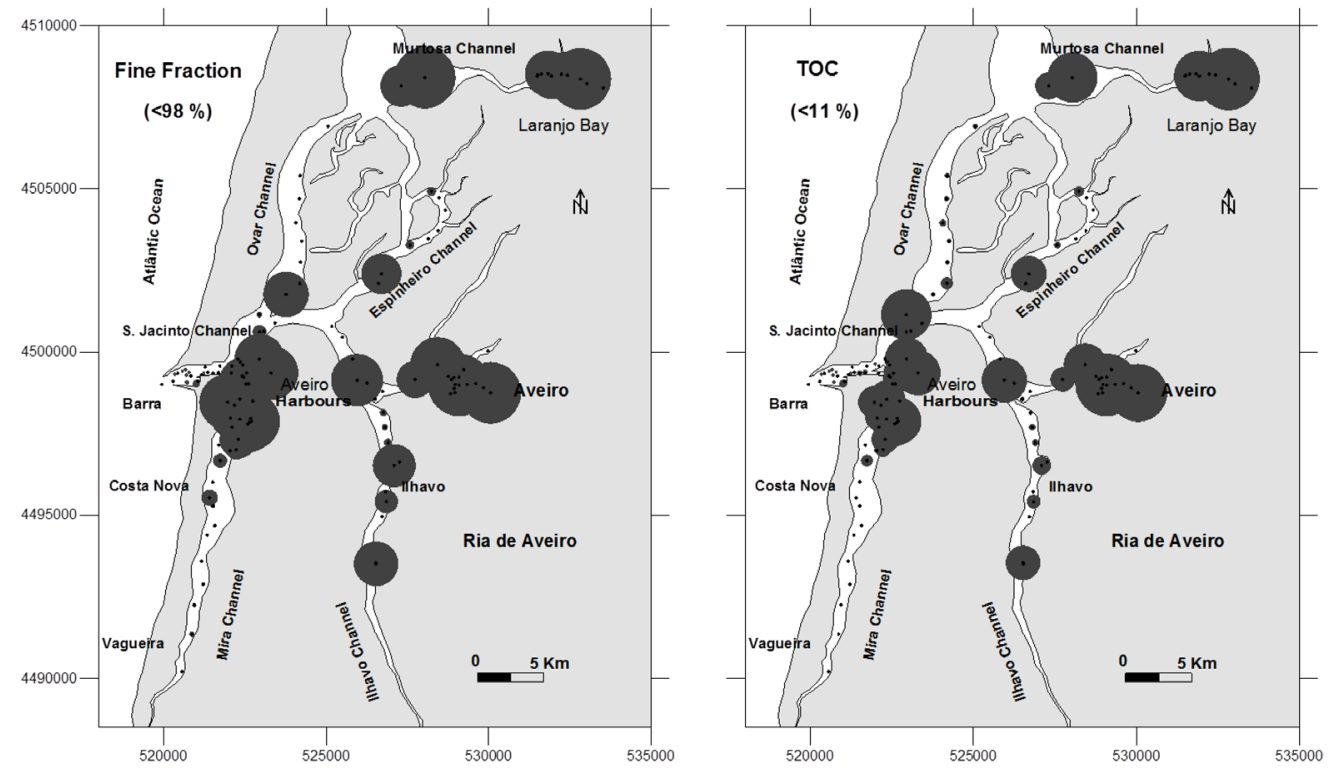

Fig.. 2. - Maps of distribution of proportion of fine fraction $(<63$ $\mu \mathrm{m})$ and TOC in the studied area. The values range is indicated in the figure. Dimension of grey balls are proportional to values of each site.

Fig. 2. - Mapas de distribución de la proporción de fracción fina ( $<63$ micras) y TOC en el área estudiada. El rango de valores se indica en la figura. Las dimensiones de las bolas de color gris son proporcionales a los valores de cada sitio.

als in the Ria de Aveiro channels are yet unknown, the average of the total concentration of these elements in 87 sediment samples, selected among the results of 215 samples collected in the studied area for their lower concentrations, were used as a reference.

Samples with a low number of living foraminifers were not used in statistical analysis relating biotic and abiotic data. Thus, only a set of 86 samples is being analyzed in this study by multivariable statistical methods, comparing grain size, geochemical characteristics, redox potential and benthic foraminifera living assemblages. Canonical analysis was carried out with the MVSP 3.1@ software package. Principal component analysis was performed using Statistical@package 7.

In order to eliminate the influence of particle size, the ratio of toxic elements with $\mathrm{Al}$ (associated mostly with clay minerals) was determined (As/Al, $\mathrm{Cd} / \mathrm{Al}, \mathrm{Cr} / \mathrm{Al}, \mathrm{Cu} /$ $\mathrm{Al}, \mathrm{Ni} / \mathrm{Al}, \mathrm{Pb} / \mathrm{Al}$ and $\mathrm{Zn} / \mathrm{Al}$ ). Although $\mathrm{Fe}$ and $\mathrm{Al}$ are not considered toxic elements, high concentrations of these chemical elements can also be markers of anthropogenic activity. Abiotic and biotic data used in canonical analysis were transformed using $\log _{2}$.

\section{Results}

\subsection{Sedimentological and geochemical analyses}

Sedimentary samples were collected at water depths varying between $0.5-30 \mathrm{~m}$. Water temperatures varied between $15-26^{\circ} \mathrm{C}$ and salinity between $6-34$. Temperature variability depends on tidal phase and season. Lower salinities were measured in inner lagoonal areas near the fresh water sources. In sediments, Eh values ranged between -12 and $-408 \mathrm{mV}$, and $\mathrm{pH}$ between 6.0-9.9. The lower $\mathrm{pH}$ values are generally found in the innermost areas of the lagoon. Results analyzed in this work are included in appendix 1. Maximum, minimum and medium values of each variable are presented in this appendix.

Sediment grain size is heterogeneous in the studied area. The sediment content in fine fraction $(<63 \mu \mathrm{m})$ reaches about $98 \%$ (Fig. 2). TOC content in dry sediments ranges between $0.2-12 \%$ (Fig. 2). Coarser sediments with low TOC content are common in the most hydrodynamic and deeper areas of the navigable channels. Finer sediments richer in TOC were found in intertidal and mud flat parts under the influence of lower hydrodynamic conditions. In these areas, lower Eh values were found in general.

Concentrations of $\mathrm{Al}, \mathrm{As}, \mathrm{Cd}, \mathrm{Cr}, \mathrm{Cu}, \mathrm{Fe}, \mathrm{Ni}, \mathrm{P}, \mathrm{Pb}$ and $\mathrm{Zn}$ increase significantly in some zones of Ria de Aveiro, such as: Laranjo Bay (Murtosa Channel), Aveiro Town and Aveiro Harbours, where the values for the load pollution index are higher (Fig. 3).

SCE results show that, in the 17 studied sites, most of the concentration of the major elements, such as $\mathrm{Al}$ and $\mathrm{Fe}$, are retained in the resistant mineralogical phase. Lead, $\mathrm{Cu}, \mathrm{Ni}$ and As concentrations are also included mostly in the resistant mineralogical phase (Fig. 4). However, relatively high concentrations of $\mathrm{Zn}$ and $\mathrm{Cd}$ are bioavailable (Fig. 5), being adsorbed by clay minerals and organic matter and co-precipitated with carbonates.

Total bioavailable concentrations determined by SCE of $\mathrm{As}, \mathrm{Cd}, \mathrm{Cu}, \mathrm{Ni}, \mathrm{Pb}$ and $\mathrm{Zn}$, all of which are considered toxic elements, are plotted in Fig. 6. This plot shows that $\mathrm{Zn}$ is the toxic element with the highest bioavailable concentration in the area. The bioavailable concentrations of $\mathrm{As}, \mathrm{Cd}, \mathrm{Cu}, \mathrm{Ni}, \mathrm{Pb}$ and $\mathrm{Zn}$ are higher in Laranjo Bay, due to the Chemical Industrial Complex of Estarreja, and in 


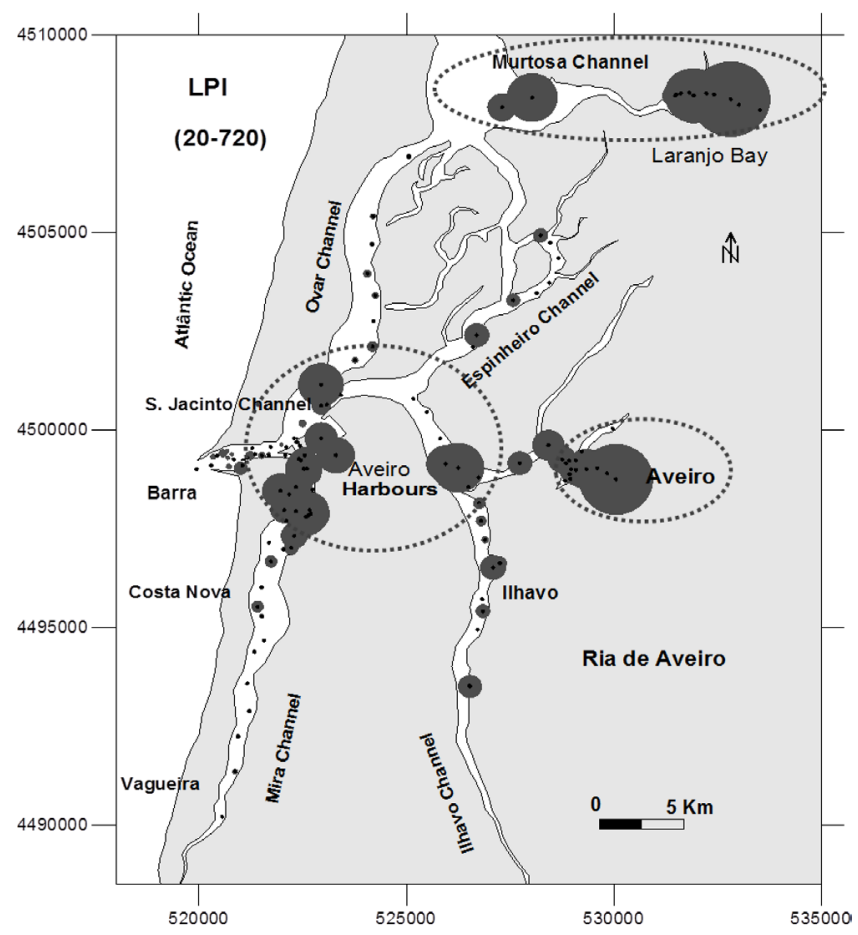

Fig. 3. - Load Pollution Index (LPI) values based on the TDS concentrations of: $\mathrm{As}, \mathrm{Cu}, \mathrm{Cr}, \mathrm{Ni}, \mathrm{Pb}, \mathrm{Zn}$ and $\mathrm{Cd}$. The values range is indicated in the figure. Dimension of grey balls are proportional to values of each site.

Fig. 3. - Valores del índice de carga de contaminación basados en la concentración de TDS de: $\mathrm{As}, \mathrm{Cu}, \mathrm{Cr}, \mathrm{Ni}, \mathrm{Pb}$, $\mathrm{Zn}$ y $\mathrm{Cd}$. El rango de valores se indica en la figura. Las dimensiones de las bolas de color gris son proporcionales a los valores de cada sitio.

Aveiro City, because of the legacy of past industrial activities, such as ceramics and glass, according to Martins et al. (2010). In Espinheiro Channel (near Cacia's Industrial area, which houses a pulp mill factory), relatively high bioavailable concentrations of $\mathrm{As}, \mathrm{Cu}, \mathrm{Pb}$ and $\mathrm{Zn}$ were found. However, this area was not identified by LPI as a critically contaminated zone.

\subsection{Benthic foraminifera analysis}

About 195 living benthic foraminifer species were recognized in Ria de Aveiro The list of species was included in appendix 1, as well the percentage of the most frequent species.

Benthic foraminifera results showed that only very few specimens have dimensions larger than $500 \mu \mathrm{m}$ in this area. The living benthic foraminifera abundance $(\mathrm{n} . \% / \mathrm{g})$ is lower than $\approx 825$ (Fig. 7). Foraminifera density decreases in gravel sandy and sandy sediments found in areas affected by stronger currents, and in low-salinity waters. Living foraminifera are also rare in calmer zones where

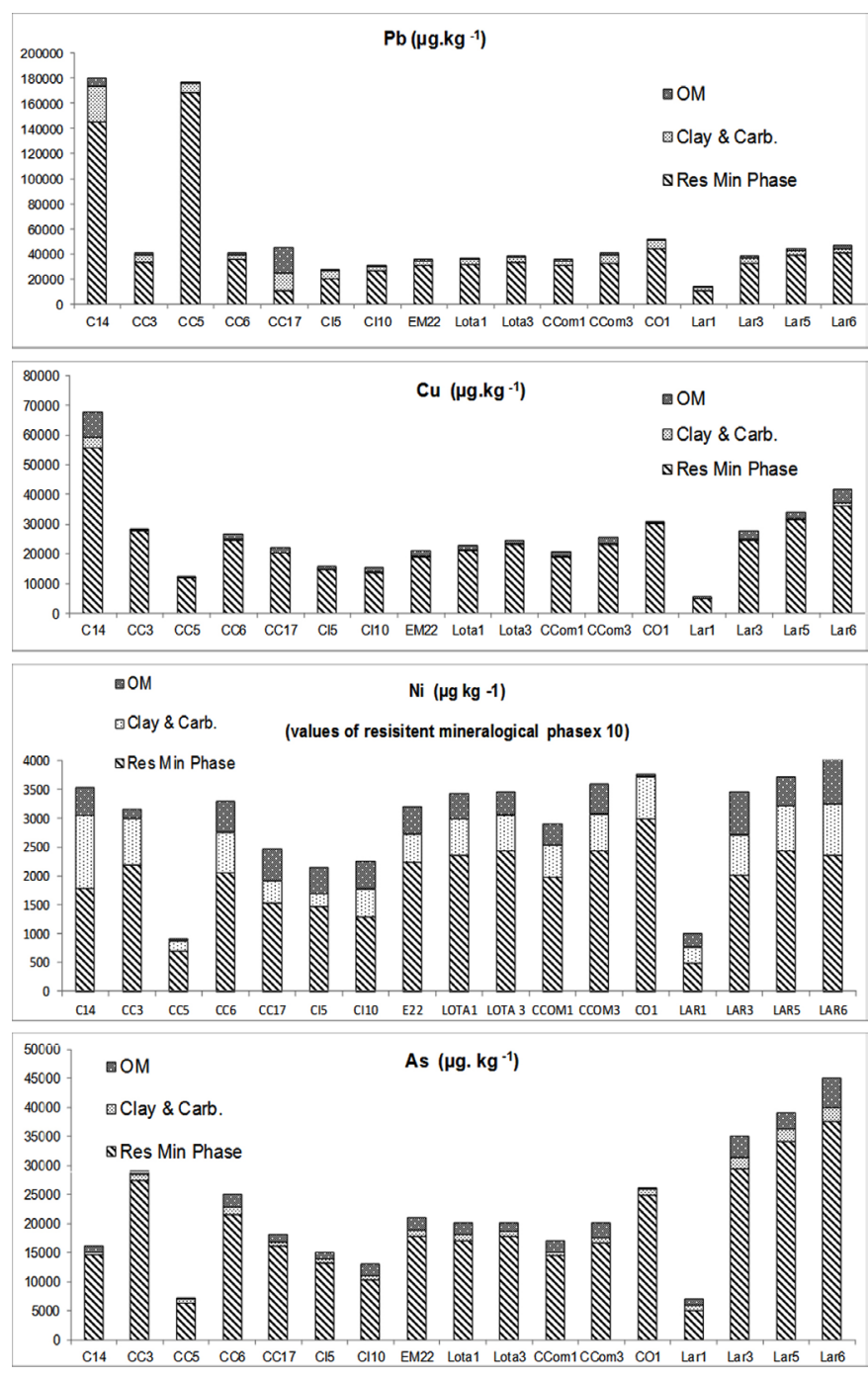

Fig. 4. - Concentrations of $\mathrm{Pb}, \mathrm{Cu}, \mathrm{Ni}$ and $\mathrm{As}$ (SCE) retained in the resistant mineralogical phase (Res Min Phase) of the sediments, associated with exchangeable cations, adsorbed by clay minerals (Clay \& Carb.) and associated with organic matter (OM), are represented with different patterns. Stations with higher bioavailable concentrations: Laranjo Bay - Lar1, Lar3, Lar5, Lar6; Aveiro Town - C14; Espinheiro Channel - CC3, CC5, CC6, CC17. Other locations: Ílhavo Channel - CI5, CI10; lagoon mouth - EM 22; Aveiro Harbours - Lota1, Lota3, CCom1 and CCom2.

Fig. 4. - Las concentraciones de $\mathrm{Pb}, \mathrm{Cu}$, Ni y As (SCE), retenido en la fase mineralógica resistente (Res Min Phase) de los sedimentos, asociadas con cationes intercambiables, adsorbido por los minerales de arcilla (Clay \& Carb.) y asociadas con la materia orgánica $(\mathrm{OM})$, están representadas con diferentes patrones. Estaciones con concentraciones disponibles más altas: Bahía de Laranjo - Lar1, Lar3, Lar5, Lar6; Ciudad de Aveiro - C14; Canal de Espinheiro - CC3, CC5, CC6, CC17. Otras localidades: Canal de Ílhavo-CI5, CI10; entrada de la laguna - EM22; Puerto de Aveiro - Lota1, Lota3, CCom1 y CCom2. 
the deposition of muddy sediments is continuous, such as in the west side of Mira Channel (near the lagoon entrance) and in hypohaline waters located at inner lagoonal areas connected with the rivers and riverine bodies, where diversity and equitability tend to decrease. The number of species per sample (S) is $<28$ (Fig. 7), Shannon index values $(\mathrm{H})$ are $<2.85$ and equitability $(\mathrm{E})$ values are $<1.37$.

The living foraminifera assemblages are comprised mainly of hyaline carbonated specimens. Most of the lagoon channel assemblages are dominated by Haynesina germanica $(<79 \%)$, Ammonia tepida $(<73 \%)$ and Elphidium spp. $(<64 \%$; including species such as $E$. gerthi, E. articulatum, E. excavatum, E. crispum and E. complanatum). In the sandy sediments of the lagoon entrance under active currents, one can find species such as Lobatula lobatula ( $<14 \%$; Fig. 8), Cibicides ungerianus $(<20 \%)$, Planorbulina mediterranensis $(<39 \%$; Fig. 8) and Gavelinopsis praegeri $(<5 \%)$. In this area, at the bottom of the navigable channels, where currents are strong, "attached" agglutinated species can be found, such as Lepidodeuterammina ochracea $(<52 \%$; Fig. 8$)$, Tiphotrocha concava ( $<33 \%$; Fig. 8), Remaneica helgolandica $(<13 \%)$, Septotrochammina gonzalezi $(<11 \%)$ and Trochammina haynesi $(<5 \%)$. Cribrostomoides jeffreysi $(<5 \%)$ and Reophax dentaliniformis $(<3 \%)$ are also found in areas located near the lagoon entrance, but in zones characterized by calmer hydrodynamic conditions. Bolivinids can be also found there $(<66 \%)$, represented mostly by Bolivina ordinaria ( $<62 \%$; Fig. 8 ) and Bolivina pseudoplicata $(<13 \%)$, Nonionella stella $(<18 \%$; Fig. $8)$ and buliminids $(<15 \%$; mostly comprised of Bulimina elongata/gibba and Buliminella elegantissima). This group is more abundant in muddy sediments deposited in protected areas (by harbour structures), under lower current velocity. Miliolids with porcelanous tests (represented mostly by Quinqueloculina seminulum; $<47 \%$ ), reach higher proportions, in general, under active currents, especially near the lagoon mouth and in Aveiro city

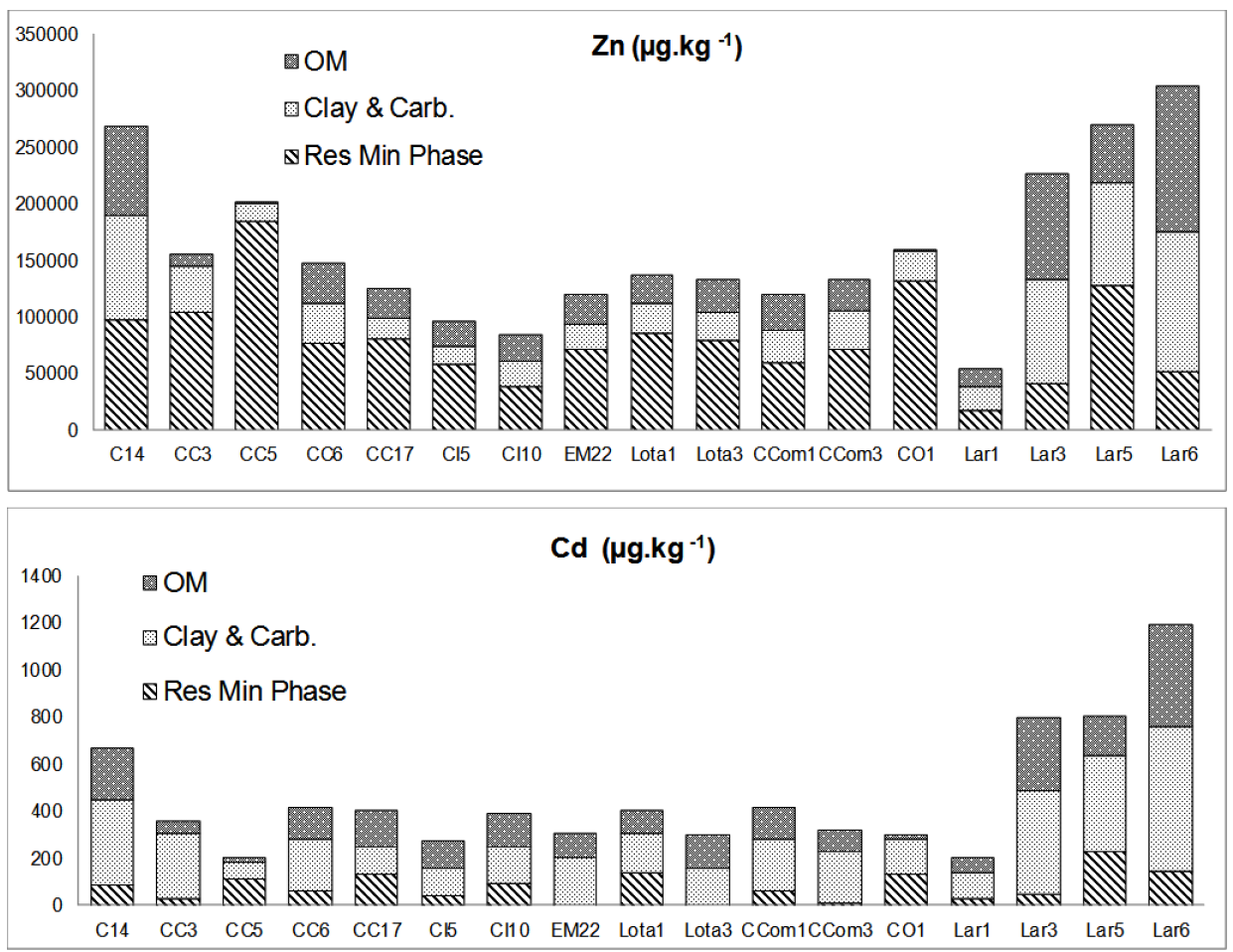

Fig. 5. - Concentrations of $\mathrm{Zn}$ and $\mathrm{Cd}(\mathrm{SCE})$ retained in the resistant mineralogical phase (Res Min Phase) of the sediments, associated with exchangeable cations, adsorbed by clay minerals (Clay \& Carb.) and associated with organic matter $(\mathrm{OM})$ are represented with different patterns. Stations with higher available concentrations: Laranjo Bay - Lar1, Lar3, Lar5, Lar6; Aveiro Town - C14; Espinheiro Channel - CC3, CC5, CC6, CC17. Other locations: Ílhavo Channel - CI5, CI10; lagoon mouth - EM22; Aveiro Harbours - Lota1, Lota3, CCom1 and CCom2.

Fig. 5. - Las concentraciones de Zn y Cd (SCE), retenido en la fase de mineralógica resistente (Res Min Phase) de los sedimentos, asociadas con cationes intercambiables, adsorbido por los minerales de arcilla (Clay \& Carb.) y asociados con la materia orgánica $(\mathrm{OM})$, están representadas con diferentes patrones. Estaciones con concentraciones disponibles más altas: Bahía de Laranjo - Lar1, Lar3, Lar5, Lar6; Ciudad de Aveiro - C14; Canal de Espinheiro - CC3, CC5, CC6, CC17. Otras localidades: Canal de Ílhavo - CI5, CI10; entrada de la laguna - EM22; Puerto de Aveiro - Lota1, Lota3, CCom1 y CCom2. 


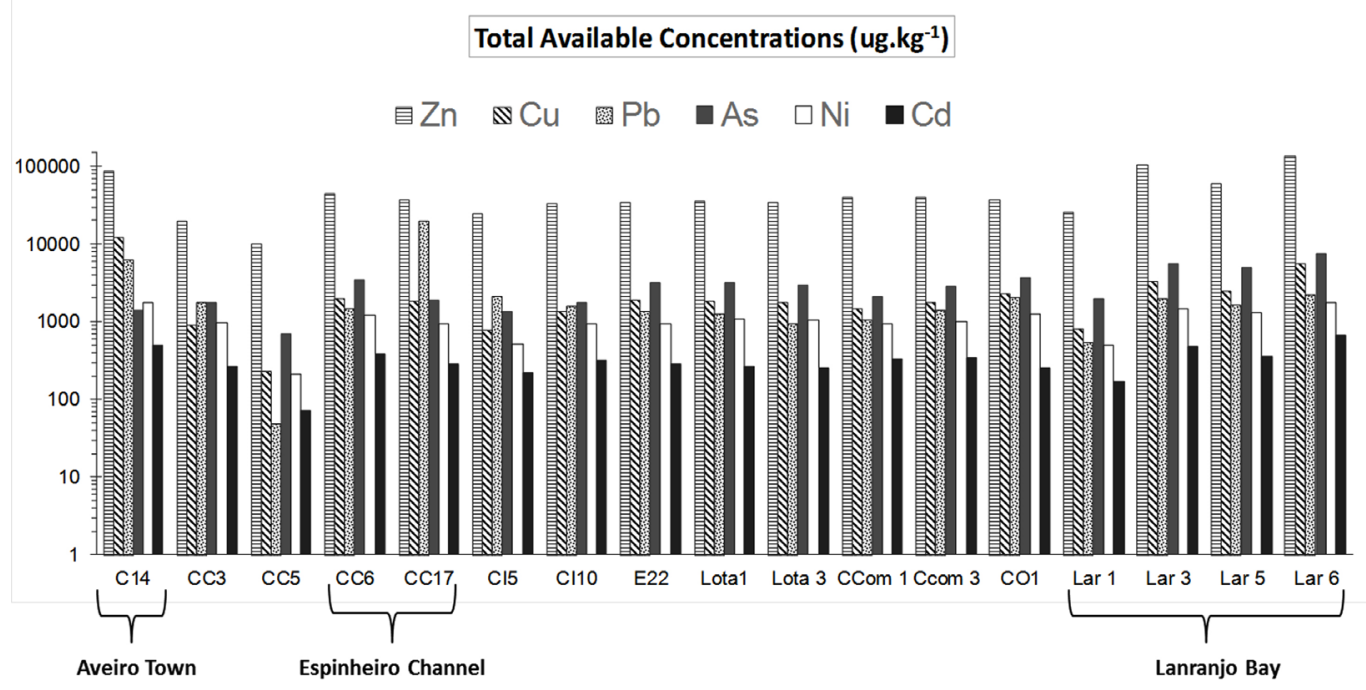

Fig. 6. - Total available concentrations (ug. $\mathrm{kg}^{-1}$ ) of $\mathrm{Zn}, \mathrm{Cu}, \mathrm{Pb}, \mathrm{As}, \mathrm{Ni}$ and $\mathrm{Cd}$ (adsorbed by clay and organic matter and co-precipitated with carbonates) in the sediments of sites with higher available concentrations: Laranjo Bay - Lar1, Lar3, Lar5, Lar6; Aveiro Town - C14; Espinheiro Channel - CC3, CC5, CC6 and CC17. Other locations: Ílhavo Channel-CI5, CI10; lagoon mouth - E 22; Aveiro Harbours - Lota1, Lota3, CCom1 and CCom3. A logarithmic scale was applied on the y-axis.

Fig. 6. - Las concentraciones totales disponibles (ug. $\mathrm{kg}^{-1}$ ) de $\mathrm{Zn}, \mathrm{Cu}, \mathrm{Pb}, \mathrm{As}, \mathrm{Cd}$ y $\mathrm{Ni}$ (adsorbido por la arcilla y materia orgánica y co-precipitado con carbonatos) en los sedimentos de los lugares con concentraciones disponibles más altas: Bahía de Laranjo - Lar1, Lar3, Lar5, Lar6; Ciudad de Aveiro - C14; Canal de Espinheiro - CC3, CC5, CC6, CC17. Otras localidades: Canal de Ílhavo - CI5, CI10; entrada de la laguna - EM22; Puerto de Aveiro - Lota1, Lota3, CCom1 y CCom2. En el eje Y se aplicó una escala logarítmica.

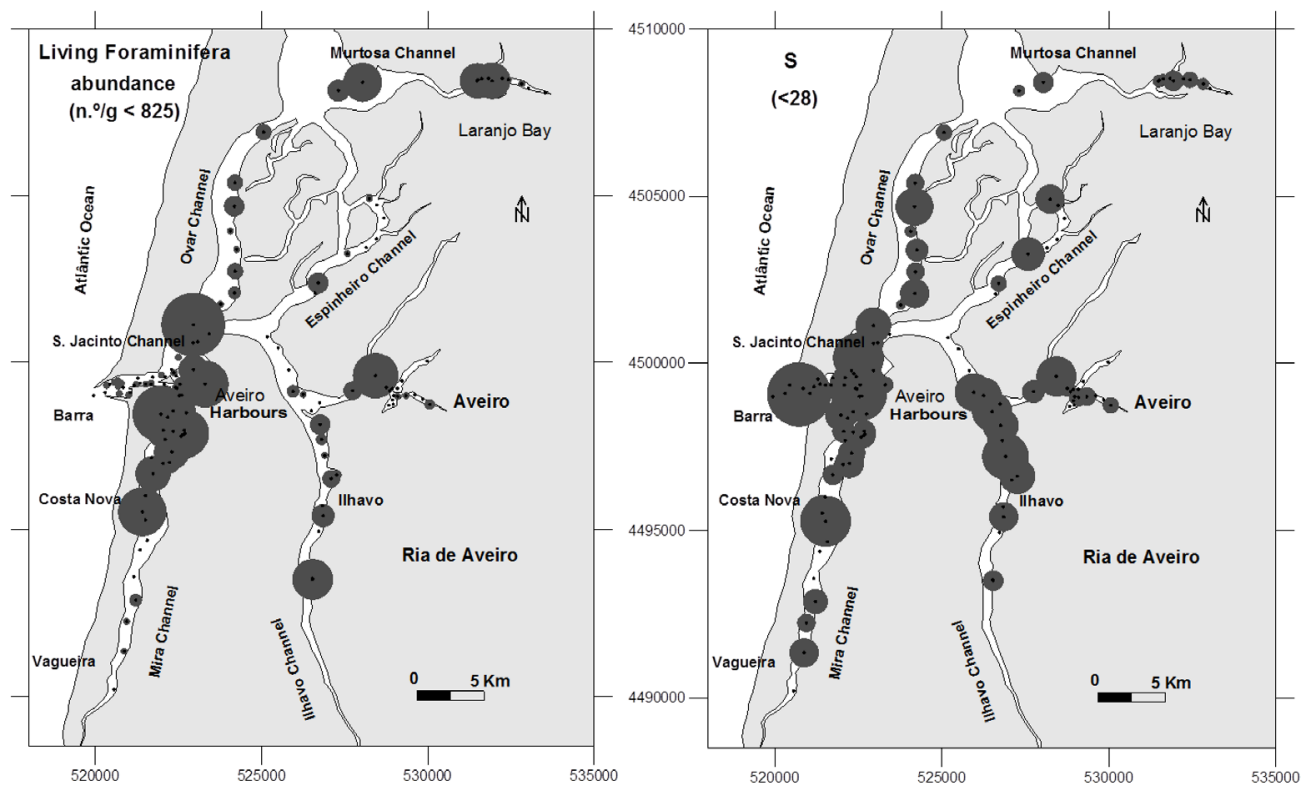

Fig. 7. - Maps of distribution of living foraminifera abundance (n. $\left.{ }^{\circ} / \mathrm{g}\right)$ and number of species per sample (S) in the studied area. The values range is indicated in the figure. The values of living foraminifera abundance were converted by $\log _{2}$, aiming at to obtain a more clear idea of graphic representation. Dimension of grey balls are proportional to values of each site.

Fig. 7. - Mapas de distribución de la abundancia de foraminíferos vivos (n. $\%$ g) y del número de especies por muestra (S) en el área estudiada. El rango de valores se indica en la figura. Los valores de abundancia de foraminíferos vivos fueron convertidos por $\log _{2}$, con el objetivo de obtener una idea más clara de la representación gráfica. Las dimensiones de las bolas de color gris son proporcionales a los valores de cada sitio. 
channels. The proportion of Trochammina inflata $(<35 \%)$ and Miliammina fusca $(<11 \%)$ increases in low-salinity waters of inner lagoonal areas. The minimum relative abundance of all these species is zero, thus the higher values were indicated

\subsection{Data analysis}

Figure 9 displays the results of the canonical analysis. This analysis includes values for fine fraction (\%), TOC $(\%), \mathrm{Al}$ concentrations, ratios of $\mathrm{As} / \mathrm{Al}, \mathrm{Cd} / \mathrm{Al}, \mathrm{Cr} / \mathrm{Al}$, $\mathrm{Cu} / \mathrm{Al}, \mathrm{Fe} / \mathrm{Al}, \mathrm{Ni} / \mathrm{Al}, \mathrm{Pb} / \mathrm{Al}$ and $\mathrm{Zn} / \mathrm{Al}$ (geochemical data analyzed by TDS), and percentages of the most abundant living species/groups of benthic foraminifera (considering their percentage and occurrence in order to avoid statistical redundancy), in the area, such as $H$. germanica, A. tepida, miliolids, agglutinated foraminifera, Elphidium spp. and B. elongata/gibba. Canonical analysis: i) separates fine fraction (Fines), $\mathrm{Al}$ concentrations and the values of the ratios $\mathrm{As} / \mathrm{Al}, \mathrm{Cd} / \mathrm{Al}, \mathrm{Cr} / \mathrm{Al}, \mathrm{Cu} / \mathrm{Al}, \mathrm{Fe} / \mathrm{Al}$, $\mathrm{Ni} / \mathrm{Al}, \mathrm{P} / \mathrm{Al}, \mathrm{Pb} / \mathrm{Al}$ and $\mathrm{Zn} / \mathrm{Al}$ from most of the biological variables. However, H. germanica and A. tepida distribution is explained by the same axis, as well as Elphidium spp., which displays a lower correlation to the other variables; ii) bolivinids and B. elongata/gibba are joined with TOC and Eh (x -1; i.e., negative Eh values); these species are known to be associated with high flux of organic matter and to survive in low oxygenated environments, where the stress caused by predation and competition is reduced (Bernhard and Sen Gupta, 1999). iii) miliolids and agglutinated species are together with $\mathrm{Pb} / \mathrm{Al}$.

Correlations between the distribution of the total bioavailable concentration of $\mathrm{As}, \mathrm{Cd}, \mathrm{Cu}, \mathrm{Ni}, \mathrm{Pb}$ and $\mathrm{Zn}$, the main species/group of species percentage (A. tepida, $H$. germanica, bolivinids, buliminids, miliolids, Elphidium spp., agglutinated spp.) and Shannon index values (H), used as an index of diversity, were submitted to principal components analysis (PCA). PCA results considering the first two factors, which explain most of data variability $(0.53 \%)$, are plotted in Fig. 10 . The first factor is more associated with metal concentration and the second one with foraminifera. Table 1 displays Pearson correlations between these variables.

\section{Discussion}

Values for foraminifera abundance, diversity and equitability are in general low in Ria de Aveiro, when compared with some shelf environments (Martins et al., 2006; 2007). Diversity values are typical of estuarine environments (as was described by, for instance, Debenay et al., 2006; Murray, 1991). One or two species comprise
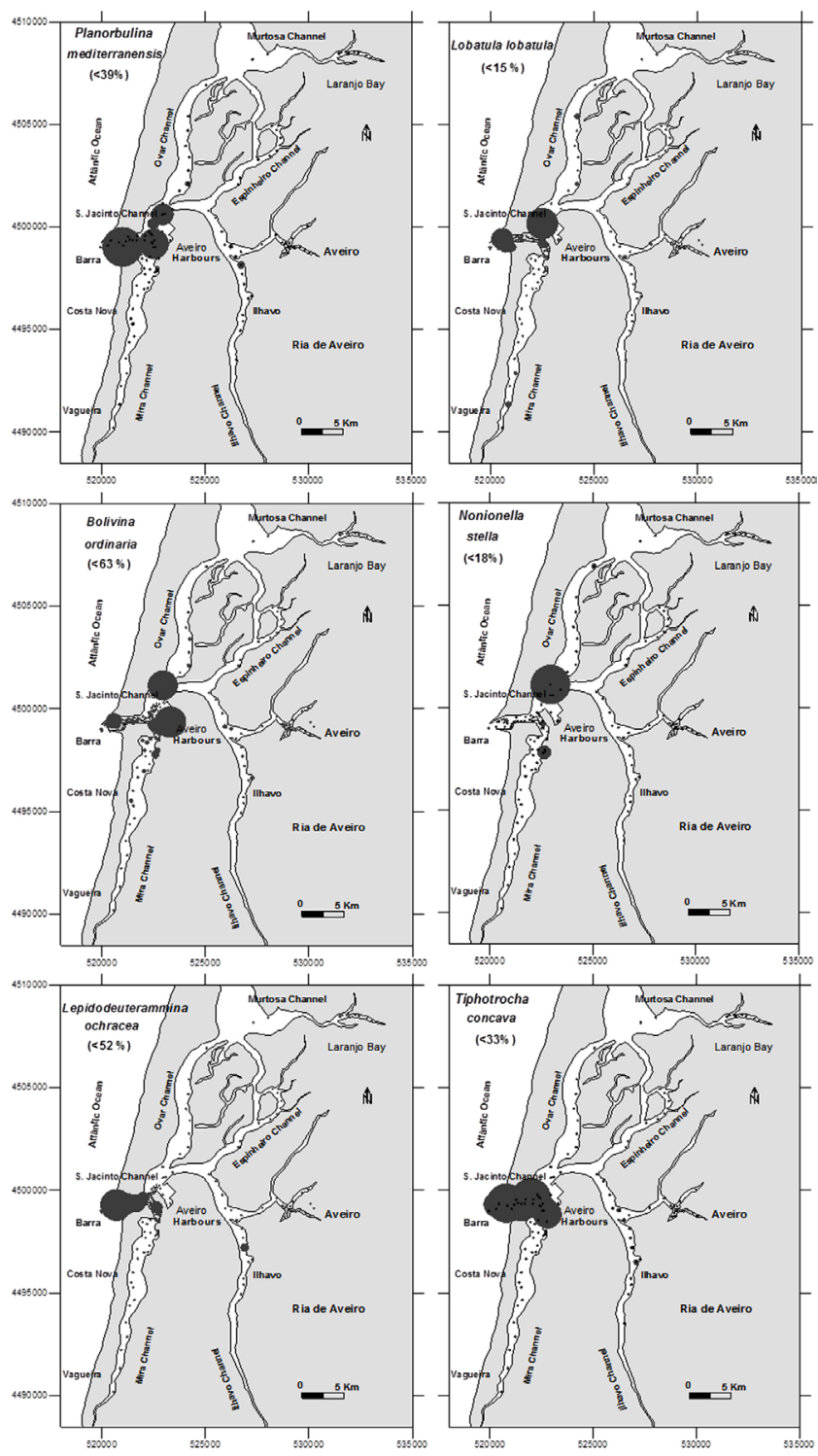

Fig. 8. - Maps of distribution of living foraminifera species (\%): Lobatula lobatula, Planorbulina mediterranensis, Bolivina ordinaria, Nonionella stella, Lepidodeuterammina ochracea and Tiphotrocha concava, in the studied area. The values range is indicated in the figure. Dimension of grey balls are proportional to values of each site.

Fig. 8. - Mapas de distribución de las especies de foraminíferos vivos (\%): Lobatula lobatula, Planorbulina mediterranensis, Bolivina ordinaria, Nonionella stella, Lepidodeuterammina ochracea y Tiphotrocha concava, en el área estudiada. El rango de valores se indica en la figura. Las dimensiones de las bolas de color gris son proporcionales a los valores de cada sitio.

most of the living assemblages in most of the studied sites. These data reveal high environmental stress for foraminifera leading to a prevalence of high species dominance in the area. Several kinds of stressors, including current velocities (described by Vaz and Dias, 2008; Dias et al., 2003, 2000, 1999) that cause sediment remobiliza- 


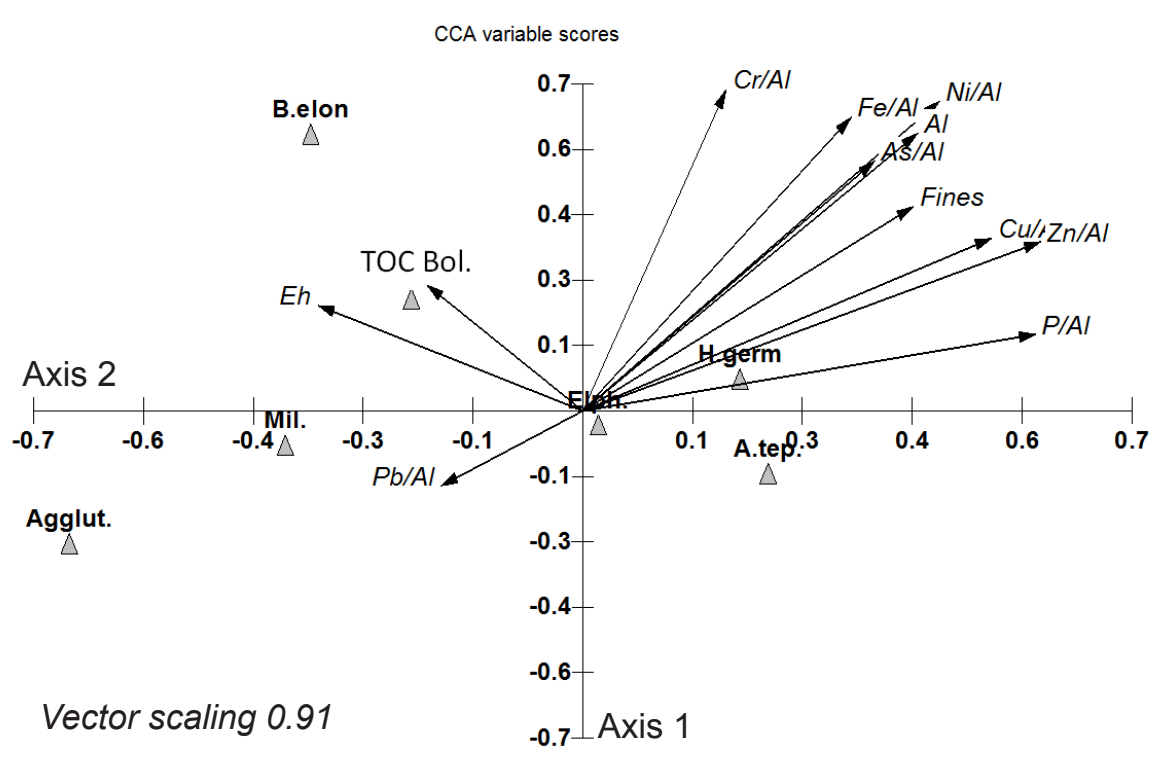

Fig. 9. - Canonical analysis based on abiotic and biotic data (transformed by $\log _{2}$ ): Eh, Fines (fine fraction, $<63 \mu \mathrm{m}$ ) and TOC percentage, concentrations of $\mathrm{Al}$, values of ratios $\mathrm{Cu} / \mathrm{Al}, \mathrm{Pb} / \mathrm{Al}, \mathrm{Zn} / \mathrm{Al}, \mathrm{Ni} / \mathrm{Al}, \mathrm{Fe} / \mathrm{Al}, \mathrm{As} /$ $\mathrm{Al}, \mathrm{P} / \mathrm{Al}, \mathrm{Cr} / \mathrm{Al}$ (geochemical data analysed by TDS), and percentage of living $H$. germanica (H.germ.), A. tepida (A.tep.), miliolids (Mil.), agglutinated (Agglut.), Elphidium spp. (Elph.), bolivinids (Bol.) and B. elongata/gibba (B.elon).

Fig. 9. - Análisis canónico de datos bióticos y abióticos (transformado por $\log _{2}$ ): Eh, finos (fracción fina, $<63 \mu \mathrm{m}$ ) y el porcentaje de TOC, las concentraciones de $\mathrm{Al}$, valores de los coeficientes $\mathrm{Cu} / \mathrm{Al}, \mathrm{Pb} / \mathrm{Al}, \mathrm{Zn} / \mathrm{Al}, \mathrm{Ni} / \mathrm{Al}$, $\mathrm{Fe} / \mathrm{Al}, \mathrm{As} / \mathrm{Al}, \mathrm{P} / \mathrm{Al}, \mathrm{Cr} / \mathrm{Al}$ (datos geoquímicos analizados por TDS) y porcentaje de las especies vivas $H$. germanica (H.germ.), $A$. tepida (A.tep.), miliolids (Mil.), agglutinated (Agglut.), Elphidium spp. (Elph.), bolivinids (Bol.) y B. elongata/gibba (B.elon).

tion (Plecha et al., 2010) or high sedimentation (Lopes and Dias, 2007), salinity variation (Almeida et al., 2005; Vaz et al., 2005), oxygen depletion (Lopes et al., 2008; Lopes and Silva, 2006) and pollutant accumulation (e.g. Pereira et al., 2005, 1998a), may affect benthic foraminifera assemblages in this system.

One of the most problematic factors affecting the abundance of foraminifera in Ria de Aveiro is current velocity. In many places of the deepest navigable channels near the lagoon mouth, where the current velocity is too strong (higher than $2 \mathrm{~m} / \mathrm{s}$, according to Vaz and Dias, 2008 and Dias et al., 2000) and causes great instability of the substrate, living foraminifers are rare. On the other hand, weak currents allow the deposition of fine-grained sediments in other areas, creating high-sedimentation environments, like at the beginning of the Mira Channel. At this location, the sediment deposition persistently buries the living assemblages, preventing their development. The environmental conditions generated by the hydrodynamism are the main reason why out of a total of 215 sites, only 86 had a sufficient number of foraminifers to characterize the assemblage.

Another limiting factor for the foraminifera of Aveiro lagoon is salinity. Ria de Aveiro is a polyhaline system. Several species found in the studied samples have positive significant correlations with salinity, i.e., they are more common in lagoonal areas under high marine influence, such as: B. elongata/gibba, B. ordinaria, B. pseudoplicata, $C$. ungerianus, E. gerthi, E. complanatum, $G$. praegeri, L. lobatula, L. ochracea, P. mediterranensis, $T$. haynesi, S. gonzalezi and T. concava. Most of the lagoon- al sites are dominated by $A$. tepida and $H$. germanica. $Q$. seminulum is spread over many lagoonal areas influenced by tides. This species is common in shelf marine and lagoonal hypo to hypersaline waters (Murray, 1991). In the inner lagoonal areas, located near the freshwater sources, the salinity varies considerably throughout the year. In these areas, agglutinated species increase, including, for instance, Trochammina inflata and M. fusca. These species are characteristic of the low salt marshes in numerous estuaries (e.g. Barbero et al., 2004; Edwards et al., 2004; Ruiz et al., 2004); they are able to live in areas with higher erratic values of salinity. Thus, in the study area, salinity has a strong influence on benthic foraminifera assemblage composition and, in hypohaline waters, on their abundance and diversity.

Potential redox was used in this work as an indirect measure of oxygenation in the surface sediments (in the first $\approx 5 \mathrm{~cm}$ of the sedimentary column). More negative values of Eh are, in general, related to lower oxic environments. Low oxic conditions are established in finegrained sediments rich in organic carbon due to anaerobic degradation of organic matter and difficult oxygen renovation of pore waters. Most of the species/groups of species analyzed in this work have low correlation with Eh values. Water in Ria de Aveiro is frequently renewed. Tides are semidiurnal, with an average range, at the inlet, of about $2 \mathrm{~m}$, and maximum and minimum ranges of 3.2 $\mathrm{m}$ (spring tide) and $0.6 \mathrm{~m}$ (neap tide), respectively (Dias et al., 2000). The tidal prism of the lagoon, for (maximum) spring tide and (minimum) neap tide, is estimated as $136.7 \times 10^{6} \mathrm{~m}^{3}$ and $34.9 \times 10^{6} \mathrm{~m}^{3}$, respectively (Lopes 
Fig. 10. - Principal components analysis of the following variables: total available concentrations of $\mathrm{Zn}, \mathrm{Cd}, \mathrm{Ni}, \mathrm{Cu}, \mathrm{As}, \mathrm{Hg}$ and $\mathrm{Pb}$, Shannon-Index values $(\mathrm{H})$, percentage of living miliolids (Miliol.), Elphidium spp. (Elph.), A. tepida (A.tep.), H. germanica (H.germ.), agglutinated species (Agglut.), buliminids (Bulim.) and bolivinids (Boliv.).

Fig. 10. - Análisis de componentes principales de las siguientes variables: el total de las concentraciones disponibles de $\mathrm{Zn}, \mathrm{Cd}, \mathrm{Ni}, \mathrm{Cu}$, como $\mathrm{Hg}$, y $\mathrm{Pb}$, valores de índice de Shannon $(\mathrm{H})$, el porcentaje de especies vivas: miliolideos (Miliol.), Elphidium spp. (Elph.), A. tepida (A.tep.), H. germanica (H.germ.), las especies aglutinadas (Agglut.), buliminideos (Bulim.) y bolivinideos (Boliv.).

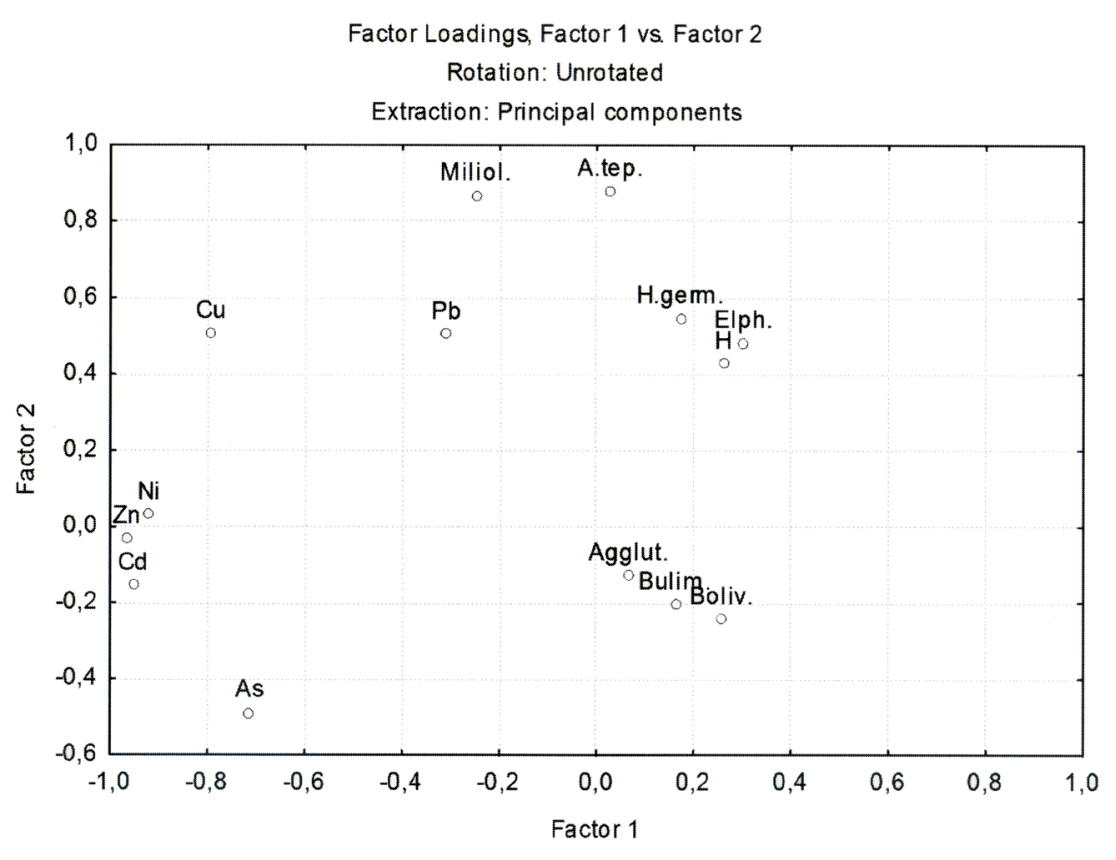

et al., 2006). Hence, the total mean estimated freshwater input is very small $(2.5 \%)$, when compared to the mean tidal prism at the mouth (approximately $70 \times 10^{6}$ $\mathrm{m}^{3}$ ). This also explains the lagoon vertical homogeneity, as described by Dias et al. (1999), and the general aeration of the water. However, the sediment-water interface is a site of intense heterotrophic activity where nutrients are generally percolated into the sediment and diffused out to the water column (Cunha et al., 1999). Aerobic respiration in coastal sediments is limited by oxygen penetration due to the resistance of the diffusive boundary layer to the flux of $\mathrm{O}_{2}$ (Yørgensen and Revsberg, 1985). The penetration varies with the composition of the sediment. In areas where muddy sediments are deposited, oxygen penetration is restricted to a few millimetres despite the supernatant water being oxygenated. Foraminifera, as a group, are the most tolerant organisms to low oxygen concentrations; however, these conditions are not favourable, in general. Only some species, such as Ammonia beccarii, E. excavatum, Q. seminulum, Eggerelloides scaber, B.ordinaria, Stainforthia fusiformis, Buliminella subfusiformis var. tenuata and N. stella, can stand very depressed levels of oxygen and even periodic anoxia (Bernhard and Sen Gupta, 1999). In areas where the sediments are poorly oxygenated, foraminifera fauna would probably live only on the sedimentary surface or in the first few millimetres below the surface, avoiding the anoxic or poorly oxygenated sediment levels (Diz and Francés, 2008). Thus, the low correlation between foraminifera of Ria de Aveiro may be explained by the different ecological niches that this group can occupy. Some species are epifaunal, inhabiting the surface of the sediments, in elevated positions, or attached to ob- jects (such as shells, vegetables, shingle), like Ammotium salsum, Arenoparrella mexicana, L. ochracea, C. ungerianus, L. lobatula, G. praegeri, T. haynesi, P. mediterranensis and $R$. helgolandica. Other species are infaunal and can inhabit relatively deep levels of the sediments (e.g., at depths $>4 \mathrm{~cm}$ below the surface, according to Rathburn and Corliss, 1994), such as M. fusca, Jadammina macrescens, A. mexicana and Haplophragmoides wilberti. Intermediate to deep infaunal species (according to the terminology of Rathburn and Corliss, 1994) can be affected by low oxygen levels. Therefore, individuals can migrate through the sedimentary column and occupy aerated habitats on surface sediments, avoiding more severe living conditions. Some other species can live in low oxic habitats (e.g., Diz and Francés, 2008; Bernhard and Sen Gupta, 1999; Rathburn and Corliss, 1994). Thus, depressed oxygen levels in the sediments below the surface may not affect many foraminifera in this system.

Is a high concentration of heavy metals disturbing the foraminifers of Ria de Aveiro? LPI values based on As, $\mathrm{Cd}, \mathrm{Cr}, \mathrm{Cu}, \mathrm{Ni}, \mathrm{Pb}$ and $\mathrm{Zn}$ concentrations (obtained by TDS) allowed the identification of three main areas with higher heavy metal concentration: Laranjo Bay (Murtosa Channel), Aveiro Town and Aveiro Harbours. In general, the highest concentrations occur in protected areas and in muddy sediments, where concentrations of Al essentially associated with the occurrence of phyllosilicates are higher.

The water is, in general, renewed in most of the lagoon due to semidiurnal tides. According to Dias et al. (2001), the particle residence time is less than 2 days at the central area of the lagoon, at the beginning of the Mira and Ílhavo channels, and extending to almost half of the S. 


\begin{tabular}{ccccccccccccccc} 
Var. & $\mathrm{As}$ & $\mathrm{Cu}$ & $\mathrm{Ni}$ & $\mathrm{Zn}$ & $\mathrm{Pb}$ & $\mathrm{Cd}$ & $\mathrm{H}$ & A.tep. & Bulim. & Boliv. & H.germ. & Miliol. & Elph. & Agglut. \\
\hline $\mathrm{As}$ & 1.00 & 0.22 & $\mathbf{0 . 6 6}$ & $\mathbf{0 . 7 9}$ & -0.30 & $\mathbf{0 . 8 5}$ & -0.14 & -0.35 & 0.01 & -0.11 & -0.19 & -0.35 & -0.21 & 0.10 \\
$\mathrm{Cu}$ & & 1.00 & $\mathbf{0 . 7 7}$ & $\mathbf{0 . 7 1}$ & $\mathbf{0 . 6 0}$ & $\mathbf{0 . 6 1}$ & -0.05 & 0.38 & -0.07 & -0.16 & 0.04 & $\mathbf{0 . 7 3}$ & -0.12 & -0.09 \\
$\mathrm{Ni}$ & & & 1.00 & $\mathbf{0 . 8 6}$ & 0.28 & $\mathbf{0 . 8 5}$ & -0.08 & -0.03 & 0.01 & -0.06 & -0.07 & 0.26 & -0.26 & -0.01 \\
$\mathrm{Zn}$ & & & & 1.00 & 0.15 & $\mathbf{0 . 9 8}$ & -0.13 & -0.03 & -0.14 & -0.22 & -0.14 & 0.20 & -0.21 & -0.12 \\
$\mathrm{~Pb}$ & & & & & 1.00 & 0.07 & -0.25 & 0.28 & -0.06 & -0.08 & -0.06 & $\mathbf{0 . 5 8}$ & -0.07 & -0.18 \\
$\mathrm{Cd}$ & & & & & & 1.00 & -0.18 & -0.12 & -0.14 & -0.24 & -0.19 & 0.06 & -0.23 & -0.08 \\
$\mathrm{H}$ & & & & & & 1.00 & 0.35 & 0.20 & 0.24 & 0.48 & 0.28 & $\mathbf{0 . 4 9}$ & -0.14 \\
$\mathrm{A.tep}$. & & & & & & & 1.00 & -0.16 & -0.24 & $\mathbf{0 . 5 6}$ & $\mathbf{0 . 6 7}$ & 0.46 & -0.09 \\
Bulim. & & & & & & & & 1.00 & $\mathbf{0 . 7 7}$ & -0.08 & -0.08 & -0.11 & -0.14 \\
Boliv. & & & & & & & & & 1.00 & -0.20 & -0.09 & -0.11 & -0.13 \\
H.germ. & & & & & & & & & & 1.00 & 0.22 & 0.16 & -0.18 \\
Miliol. & & & & & & & & & & & 1.00 & 0.31 & -0.05 \\
Elph. & & & & & & & & & & & & 1.00 & 0.26 \\
Agglut. & & & & & & & & & & & & & 1.00 \\
\hline
\end{tabular}

Table 1 - Correlation between the total bioavailable concentrations of $\mathrm{As}, \mathrm{Cu}, \mathrm{Ni}, \mathrm{Zn}, \mathrm{Pb}$ and $\mathrm{Cd}$ (adsorbed by clay and organic matter and co-precipitated with carbonates) and Shannon index values (H), A. tepida (A.tep.), Bulimina spp. (Bulim.), Bolivina spp. (Boliv.), H. germanica (H.germ.), miliolids (Milioli.), Elphidium spp. (Elph), aglutinated spp. (Agglut.). Significant correlations ( $\mathrm{p}>0.50)$ are marked in bold.

Tabla 1 - Correlación entre las concentraciones totales biodisponibles de $\mathrm{As}, \mathrm{Cu}, \mathrm{Ni}, \mathrm{Zn}, \mathrm{Pb}$ y Cd (absorbido por la arcilla y materia orgánica y co-precipitado con carbonatos) y los valores de índice de Shannon (H), A. tepida (A.tep.), Bulimina spp. (Bulim.), Bolivina spp. (Boliv.), H. germanica (H.germ.), miliolideos (Milioli.), Elphidium spp. (Elph), especies aglutinadas (Agglut.). Las correlaciones significativas $(p>0,50)$ aparecen en negrita.

Jacinto and Espinheiro channels. But in some regions particles hardly escape when released into the flood, and, in a few places, none escaped (e.g., the far end of the Mira Channel and the dendritic channels close to Varela in the northern area of the lagoon). Thus, the areas where the particle residence time is higher and where cohesive sediments are deposited can act as sinks of anthropogenic pollutants. The impact driven by urbanization and industrialization, as well as the consequent increased geochemical forcing in this system, tend to be clearer in parts where muddy sediments are deposited, under low hydrodynamic conditions.

Canonical analysis highlighted that higher concentrations of toxic elements (determined by TDS) are adverse factors for benthic foraminifera of Ria de Aveiro. But also lead us to think that species such as $H$. germanica and $A$. tepida should tolerate higher level of stress caused by these pollutants. A. tepida has been considered one of the most tolerant species to high heavy metal concentration and is used as a bio-indicator of pollution of anthropized marine sediments (Ferraro et al., 2006). H. germanica was also considered a bio-indicator of pollution by metals (Frontalini et al., 2011; Romano et al., 2008) and of pollution by metals and hydrocarbons (Armynot du Châtelet et al., 2004).

However, canonical analysis results also suggest that agglutinated foraminifera and miliolids are more tolerant to high concentrations of $\mathrm{Pb}$. Agglutinated foraminifera reach higher abundance near the lagoon mouth where spots of $\mathrm{Pb}$ pollution caused by fuel used for navigation were found. In this area, species such as L. ochracea, $T$. concava, $R$. helgolandica, S. gonzalezi and T. haynesi are very common. These species were frequently found adhered to sand particles and are probably able to track the movement of sediments under active current activity. Thus, they may not be too affected by high concentrations of $\mathrm{Pb}$ in this area, where the sediment mobility should be strong. Miliolids, represented mostly by $Q$. seminulum, are common near the Ria mouth, but also in some Aveiro channels, more specifically, in two areas with distinct hydrodynamic characteristics, where higher $\mathrm{Pb}$ concentrations were found.

We tried to confirm these results studying the correlation between total bioavailable concentration of the selected elements (obtained by SCE) and the most abundant living species/groups of benthic foraminifera in most of the 17 samples. Geochemical results revealed that most of the concentration of $\mathrm{As}, \mathrm{Cd}, \mathrm{Cu}, \mathrm{Ni}, \mathrm{Pb}$ and $\mathrm{Zn}$ is retained in the mineralogical resistant phase. However, in the most contaminated areas, such as Laranjo Bay (Murtosa Channel), Aveiro Town and Aveiro Harbours, a high total bioavailable concentration of $\mathrm{As}, \mathrm{Cd}, \mathrm{Cu}, \mathrm{Ni}, \mathrm{Pb}$ and $\mathrm{Zn}$ was found. In Espinheiro Channel, an area with relatively low LPI values, significant bioavailable concentrations of heavy metals were also found. 
PCA (Fig. 10) and Pearson correlations (Table 1) evidence that higher bioavailable concentrations of $\mathrm{As}, \mathrm{Cd}$, $\mathrm{Cu}, \mathrm{Ni}, \mathrm{Pb}$ and $\mathrm{Zn}$ generally prevents the development of large benthic foraminifera communities in the Ria de Aveiro. A. tepida, H. germanica and Elphidium spp. should be more resistant to higher bioavailable concentrations of heavy metals than bolivinids, buliminids and agglutinated foraminifera, for example. However, a differential sensitivity to pollutants may exist among the different species/groups of species of foraminifera. Our results suggest that, contrary to the opinion of Rao and Rao (1979), miliolids in Ria de Aveiro, represented mostly by $Q$. seminulum, may be more tolerant to higher bioavailable concentrations of $\mathrm{Cu}$ and $\mathrm{Pb}$ than $A$. tepida, $H$. germanica and Elphidium spp.

\section{Conclusion}

LPI values can be used as a first approach to identify polluted areas. Measurement of the sedimentary total concentrations of toxic elements is useful as a general index of contamination, but may provide inadequate or little information about their availability, mobility or toxicity for the living beings. Most of the elemental concentrations are retained in the mineralogical resistant phase, i.e., they don't affect the biota. Results presented in this work show that SCE analyses are important to evaluate the real degree of sediment contamination and their influence on benthic organisms, namely on benthic foraminifera. Areas with relatively low concentrations of heavy metals can have relatively high concentrations of bioavailable toxic elements.

Thus, the identification of the most tolerant species can change, if we consider the sedimentary total concentrations of toxic elements or the bioavailable concentrations of heavy metals (SCE). Foraminifera are generally affected by high element concentrations, but some species may have differential sensitivities. A. tepida, H. germanica and Elphidium spp. may be more tolerant to high bioavailable concentrations of toxic elements than, for instance, bolivinids and buliminids. However, Q. seminulum may be more tolerant to pollution caused by higher bioavailable concentrations of $\mathrm{Pb}$ and $\mathrm{Cu}$ than $A$. tepida, H. germanica and Elphidium spp.

Sequential chemical extraction may provide a more correct evaluation of pollution degree by heavy metals.

\section{Acknowledgements}

The authors would like to thank Sandra Donnici and an anonymous reviewer for collaborating on the improvement of this work, and Prof. João Dias (principal investigator of EMERA project) and Isabel Abrantes for collaboration in field work. The authors would like to thank Cristina Freitas, Rui Marques and Paulo Miranda for the technical support. This work was financed by the FCT (Portugal), through the EMERA Project (POCTI/ ECM/59958/2004), and by the Geobiotec Research Centre, of Aveiro University.

\section{References}

Abreu, S.N., Pereira, E., Vale, C., Duarte, A.C. (2000): Accumulation of mercury in sea bass from a contaminated lagoon (Ria de Aveiro, Portugal). Marine Pollution Bulletin 40, 293-297. doi:10.1016/ S0025-326X(99)00187-3.

Almeida, M.A., Cunha, M.A., Alcântara, F. (2005): Relationship of bacterioplankton production with primary production and respiration in a shallow estuarine system (Ria de Aveiro, NW Portugal). Microbiological Research 160, 315-328. doi. org/10.1016/j.micres.2005.02.005

Alve, E. (1995): Benthic foraminifera response to estuarine pollution. A review. Journal of Foraminiferal Research 25, 190-203. doi:10.2113/gsjfr.25.3.190

Alve, E. (1991): Benthic foraminifera in sediment cores reflecting heavy metal pollution in Sorfjord, Western Norway. Journal of Foraminiferal Research 21, 1-19. doi:10.2113/ gsjfr.21.1.1

Armynot du Châtelet, E., Amiard, J.-C., Debenay, J.-P., Geffard, A. (2003): Métaux dans le sédiment et fraction bio disponible: influence sur les peuplements de foraminifères. In: Second International Symposium on Contaminated Sediments, Quebec, 26-28, Proceedings: 311-318.

Armynot du Châtelet, E., Debenay, J.-P., Soulard, R. (2004): Foraminiferae proxies for pollution monitoring in moderatelly polluted harbors. Environmental Pollution 127, 27-40.

Barbero, R.S., Albani, A.D., Bonardi M. (2004): Ancient and modern salt marshes in the Lagoon of Venice. Palaeogeography, Palaeoclimatology, Palaeoecology 202, 229-244. http://dx.doi.org/10.1016/S0031-0182(03)00636-9

Bernhard, J. M, Sen Gupta, B.K. (1999): Foraminifera of oxygen-depleted environments. In B. K. Sen Gupta (Ed.), Modern Foraminifera, Kluwer Academic Publishers, pp. 201-216. doi:10.1007/0-306-48104-9_12

Burone, L., Valente, P., Pires-Vanin, A., Mello e Souza, S.H., Mahiques, M.M., Braca, E. (2007): Benthic foraminiferal variability on a monthly scale in a subtropical bay moderately affected by urban sewage. Scientia Marina 71, 775-792. doi:10.3989/scimar.2007.71n4775

Burone, L., Venturini, N., Sprechmann, P., Valente, P., Muniz, P. (2006): Foraminiferal responses to polluted sediments in the Montevideo coastal zone, Uruguay. Marine Pollution Bulletin 52, 61-73. doi:10.1016/j.marpolbul.2005.08.007

Carnahan, E.A., Hoare, A.M., Hallock, P., Lidz, B.H., Reich, C.D. (2009): Foraminiferal assemblages in Biscayne Bay, Florida, USA: Responses to urban and agricultural influence in a subtropical estuary. Marine Pollution Bulletin 59, 221233. doi:10.1016/j.marpolbul.2009.08.008. 
Coelho, J.P., Pereira, M.E., Duarte, A., Pardal, M.A. (2005): Macroalgae response to a mercury contamination gradient in a temperate coastal lagoon - Ria de Aveiro. Estuarine, Coastal and Shelf Science 65, 492-500. doi:10.1016/j. ecss.2005.06.020.

Coelho, J.P., Rosa, M., Pereira, M.E., Duarte, A., Pardal, M.A. (2006): Pattern and annual rates of Scrobicularia plana mercury bioacumulation in a human induced mercury gradient (Ria de Aveiro, Portugal). Estuarine, Coastal and Shelf Science, 69, 629-635. doi:10.1016/j.ecss.2006.05.027.

Cunha, M.A., Almeida, M.A., Alcântara, F. (1999): Compartments of oxygen consumption in a tidal mesotrophic estuary (Ria de Aveiro, Portugal). Acta Oecologica 20 (4), 227-235. doi:10.1016/S1146-609X(99)00143-5

Debenay, J.-P., Bicchi, E., Goubert, E., Armynot du Châtelet, E. (2006): Spatio-temporal distribution of benthic foraminifera in relation to estuarine dynamics (Vie estuary, Vendée, W France). Estuarine, Coastal and Shelf Science 67, 181197. doi:10.1016/j.ecss.2005.11.014

Dias, J.M., Lopes, J.F. (2006): Implementation and assessment of hydrodynamic, salt and heat transport models: the case of Ria de Aveiro Lagoon (Portugal). Environmental Modelling \& Software, 21, 1-15. doi:10.1016/j.envsoft.2004.09.002

Dias, J.M., Lopes, J.F., Dekeyser, I. (2003): A numerical system to study the transport properties in the Ria de Aveiro lagoon. Ocean Dynamics 53, 220-231. doi:10.1007/s10236003-0048-5

Dias, J.M., Lopes J.E., Dekeyser, I. (2001): Lagrangian Transport of Particles in Ria de Aveiro Lagoon, Portugal. Physics and Chemistry of the Earth (B), 26, 721-721. doi:10.1016/ S1464-1909(01)00076-4

Dias, J.M., Lopes, J.F., Dekeyser, I. (2000): Tidal Propagation in Ria de Aveiro Lagoon, Portugal. Physics and Chemistry of the Earth (B) 25, 369-374. doi:10.1016/S14641909(00)00028-9

Dias, J.M., Lopes, J.F., Dekeyser, I. (1999): Hydrological characterization of Ria de Aveiro lagoon, Portugal, in early summer. Oceanologica Acta 22, 473-485. doi:10.1016/S03991784(00)87681-1

Diz, P., Francés, G. (2008): Distribution of live benthic foraminifera in the Ría de Vigo (NW Spain). $M a$ rine Micropaleontology 66, 165-191. doi.org/10.1016/j. marmicro.2007.09.001Edwards, R.J., Wright, A.J., van de Plassche, O. (2004): Surface distributions of salt-marsh foraminifera from Connecticut, USA: modern analogues for high-resolution sea level studies Marine Micropaleontology 51, 1-21. doi:10.1016/j.marmicro.2003.08.002

Fatela, F., Taborda, R. (2002): Confidence limits of species proportions in microfossil assemblages. Marine Micropaleontology 45, 169-174. doi:10.1016/S0377-8398(02)00021-X

Ferraro, L., Sprovieri, M., Alberico, I., Lirer, F, Prevedello, L, Marsella, E. (2006): Benthic foraminifera and heavy metals distribution: a case study from the Naples Harbour (Tyrrhenian Sea, Southern Italy). Environmental Pollution 142, 274-87. doi:10.1016/j.envpol.2005.10.026

Frontalini, F., Rodolfo Coccioni, R. (2011): Benthic foraminifera as bioindicators of pollution: A review of Italian research over the last three decades. Revue de Micropaléontologie 54, 115-127. http://dx.doi.org/10.1016/j.revmic.2011.03.001

Horton, B.P., Edwards, R.J., Lloyd, J.M. (1999): UK intertidal foraminiferal distributions: Implications for sea-level studies. Marine Micropaleontology 36, 205-223. doi:10.1016/ S0377-8398(99)00003-1

Lopes, J.F., Silva, C.I., Cardoso A.C. (2008): Validation of a water quality model for the Ria de Aveiro lagoon, Portugal. Environmental Modelling \& Software 23, 479-494. doi:10.1016/j.envsoft.2007.07.001

Lopes, J.L., Dias, J.M. (2007): Residual circulation and sediment distribution in the Ria de Aveiro lagoon, Portugal. Journal of Marine Systems 68, 507-528. doi:10.1016/j.jmarsys.2007.02.005

Lopes, J.F., Silva C. (2006): Temporal and spatial distribution of dissolved oxygen in the Ria de Aveiro lagoon. Ecological Modelling 197, 67-88. doi:10.1016/j.ecolmodel.2006.03.012

Lopes, J.F., Dias, J.M., Dekeyser, I. (2006): Numerical Modelling of Cohesive Sediments Transport in the Ria de Aveiro Lagoon, Portugal. Journal of Hydrology 319, 176-198. doi:10.1016/j.jhydrol.2005.07.019

Lopes, J.F., Dias, J.M., Cardoso, A.C., Silva, C.I.V. (2005): The water quality of the Ria de Aveiro lagoon, Portugal: From the observations to the implementation of a numerical model. Marine Environmental Research 60, 594-628.

Martins, V., Ferreira da Silva, E., Sequeira, C., Rocha, F., Duarte, A.C. (2010): Evaluation of the ecological effects of heavy metals on the assemblages of benthic foraminifera of the canals of Aveiro (Portugal). Estuarine, Coastal and Shelf Science 87, 293-304. doi:10.1016/j.ecss.2010.01.011

Martins, V., Dubert, J., Jouanneau, J.-M., Weber, O., Silva, E. F., Patinha C., Alveirinho Dias, J. M., Rocha, F. (2007): A multiproxy approach of the Holocene evolution of shelfslope circulation on the NW Iberian Continental Shelf. Marine Geology 239, 1-18. doi:10.1016/j.margeo.2006.11.001

Martins, V., Jouanneau, J.-M., Weber, O., Rocha, F. (2006): Tracing the late Holocene evolution of the NW Iberian upwelling system. Marine Micropaleontology 59, 35-55. doi:10.1016/j.marmicro.2005.12.002

Moreira, H.M., Queiroga, H., Machado, M.M., Cunha, M.R. (1993): Environmental gradients in a southern estuarine system: Ria de Aveiro, Portugal, implication for soft bottom macrofauna colonisation. Netherlands Journal of Aquatic Ecology 27, 465-482. doi:10.1007/BF02334807

Monterroso, P., Abreu, S.N., Pereira, E., Vale, C., Duarte, A.C. (2003): Estimation of $\mathrm{Cu}, \mathrm{Cd}$ and $\mathrm{Hg}$ transported by plankton from a contaminated area (Ria deAveiro). Acta Oecologica 24, S351-S357. doi:10.1016/S1146-609X(03)00033-X

Murray, J.W. (1991): Ecology and palaeoecology of benthic foraminifera. London, Longman Scientific \& Technical: 397 p. Murray, J.W., Alve, E. (1999): Natural dissolution of modern shallow water benthic foraminifera: Taphonomic effects on the palaeoecological record. Palaeogeography, Palaeoclimatology, Palaeoecology 146, 195-209. doi:10.1016/ S0031-0182(98)00132-1

Neff, J.N. (2002): Bioaccumulation in Marine Organisms. Effect of contaminants from oil well produced water. Elsevier: $452 \mathrm{pp}$. 
Oliver, H., Lotte, A.F., Lemcke, G. (2001): Loss on ignition as a method for estimating organic and carbonate content in sediments: reproducibility and comparability of results. Journal of Paleolimnology 25, 101-110. doi:10.1023/A:1008119611481

Pereira, M.E., Lillebø A.I., Pato, P., Válega, M., Coelho, J.P., Lopes, C.B., Rodrigues, S. Cachada, A., Otero, M., Pardal, M.A., Duarte A.C. (2009): Mercury pollution in Ria de Aveiro (Portugal): a review of the system assessment. Environ. Monit. Assess. 155, 39-49. doi:10.1007/s10661-008-04161.

Pereira, M.E., Abreu, S.N., Coelho, J.P., Lopes, C.B., Pardal, M.A., Vale, C. (2006): Seasonal fluctuations of tissue mercury contents in the European shore crab Carcinus maenas from low and high contamination areas (Ria de Aveiro, Portugal). Marine Pollution Bulletin 52, 1450-1457. doi:10.1016/j. marpolbul.2006.05.006.

Pereira, M.E., Duarte, A.C., Millward, G.E., Abreu, S.N., Vale, C. (1998a): An estimation of industrial mercury stored in sediments of a confined area of the Lagoon of Aveiro (Portugal). Water Science and Technology 37, 125-130. doi:10.1016/ S0273-1223 (98)00191-7.

Pereira, M.E., Duarte, A.C., Millward, G. E., Abreu, S.N., Vale, C. (1998b): Tidal export of particulate mercury from the most contaminated area of Aveiro's Lagoon, Portugal. Science of the Total Environment 213, 157-163. doi:10.1016/ S0048-9697(98)00087-4.

Pereira, M.E. Duarte, A.C., Millward, G.E. (1995): Seasonal variability in mercury inputs into the Ria de Aveiro, Portugal. Netherlands Journal of Aquatic Ecology 29, 291-296. doi:10.1007/BF02084227

Plecha, S., Silva, P.A., Vaz, N., Bertin, X., Oliveira, A., Fortunato, A.B., Dias, J.M. (2010): Sensitivity analysis of a morphodynamic modelling system applied to a coastal lagoon inlet. Ocean Dynamics 60, 275-284. doi:10.1007/s10236010-0267-5

Ramalhosa, E., Segade, S.R., Pereira, E., Vale, C., Duarte, A. (2006): Mercury cycling between the water column and surface sediments in a contaminated area. Water Research 40, 2893-2900. doi:10.1016/j.watres.2006.05.023.
Rao, T.V., Rao M.S. (1979): Studies on pollution ecology of foraminifera of the Trivandrum Coast. Indian Journal of Marine Sciences 8, 31-35.

Rathburn, A.E., Corliss, B.H. (1994): The ecology of living (stained) deep-sea benthic foraminifera from the Sulu Sea. Paleoceanography 9, 87-150. doi:10.1029/93PA02327

Romano, E., Bergamin, L., Finoia, M.G., Carboni, M.G., Ausili, A., Gabellini, M. (2008): Industrial pollution at Bagnoli (Naples, Italy): Benthic foraminifera as a tool in integrated programs of environmental characterisation. Marine Pollution Bulletin 56, 439-457. doi:10.1016/j.marpolbul.2007.11.003

Ruiz, F., González-Regalado, M.L., Borrego, J., Abada, M., Pendón, J.G. (2004): Ostracoda and foraminifera as shortterm tracers of environmental changes in very polluted areas: the Odiel Estuary (SW Spain). Environmental Pollution 129, 49-61. doi:10.1016/j.envpol.2003.09.024

Shannon, C.E. (1948): A mathematical theory of communication. Bell System Technical Journal 27, 379-423.

Tomlinson, D.L., Wilson, J.G., Harris, C.R., Jeffrey, D.W. (1980): Problems in the assessment of heavy metal levels in estuaries and the formation of pollution index. Helgolander Meeresuntersuchugen 33, 566-575.doi:10.1007/ BF02414780

Válega, M., Lillebø, A.I., Caçador, I., Pereira, M.E., Duarte, A.C., Pardal, M.A. (2008): Mercury mobility in a salt marsh colonised by Halimione portulacoides. Chemosphere 72, 1607-161. doi:10.1016/j.chemosphere.2008.04.007

Vaz, N., Dias, J.M. (2008): Hydrographic characterization of an estuarine tidal channel. Journal of Marine Systems 70, 168-181. doi:10.1016/j.jmarsys. 2007.05.002.

Yanko, V., Arnold, A., Parker, W. (1999): Effect of marine pollution on benthic foraminifera. In: Sen Gupta, B.K. (Ed.), Modern Foraminifera, Kluver Academic: pp. 217-235.

Yanko, V., Ahmad, M., Kaminski, M.A. (1998): Morphological deformities of benthic foraminiferal tests in response to pollution by heavy metals: Implications for pollution monitoring. Journal of Foraminiferal Research 28, 177-200.

Yørgensen, B., Revsberg, N. (1985): Diffusive boundary layers and the oxygen uptake of sediments and detritus. Limnology and Oceanography 30, 111-122.

Apendix 1.-

Living benthic Foraminifera species identified in the studied samples

Acervulina inhaerens Schultze, 1854

Adelosina partschi (d'Orbigny, 1846)

Ammonia beccarii (Linné, 1758)

Ammonia tepida (Cushman, 1926)

Ammotium salsum (Cushman \& Brönnimann, 1948)

Arenoparrella mexicana (Kornfeld, 1931)

Balticammina pseudomacrescens Bronnimann, Lutze \& Whittaker, 1989

Bolivina compacta Sidebottom, 1905

Bolivina difformis (Williamson 1858)

Bolivina doniezi Cushman \& Wickenden, 1929

Bolivina goesii Cushman, 1922

Bolivina limbata var. abbreviata Heron-Allen \& Earland, 1924

Bolivina ordinaria Pheleger \& Parker, 1952

Bolivina pseudoplicata Heron-Allen \& Earland, 1930

Bolivina skagerrakensis Qvale \& Nigam, 1985

Bolivina variabilis (Williamson, 1858)

Brizalina spathulata (Williamson, 1858)
Brizalina striatula (Cushman, 1922)

Brizalina subaenariensis (Cushman, 1922)

Brizalina subspathulata (Boomgart, 1949)

Brizalina translucens Phleger \& Parker, 1951

Buccella cf. B. parkerae Anderson, 1953

Bulimina aculeata d' Orbigny, 1826

Bulimina elongata d' Orbigny, 1846

Bulimina gibba Fornasini, 1900

Bulimina marginata d’Orbibny, 1826

Buliminella elegantissima (d'Orbigny, 1839)

Buliminella subfusiformis var. tenuata Cushman, 1927

Cancris auriculus (Fichtel \& Moll, 1798)

Cassidulina crassa (d'Orbigny, 1839)

Cassidulina laevigata d'Orbigny, 1826 + C. carinata (Silvestri, 1896)

Cassidulina minuta Cushman, 1933

Cassidulina teretis Tappan, 1951

Cassidulinoides bradyi (Norman, 1881) 
Cibicides ungerianus (d'Orbigny, 1846)

Cornuloculina balkwilli (Macfayden, 1939) Cornuspira involvens (Reuss, 1850)

Cornuspirella diffusa (Heron-Allen \& Earland, 1913)

Cribroeponides criborepandus (Asano \& Uchio, 1951)

Cribrostomoides jeffreysi (Williamson, 1858)

Cribrostomoides subturbinata (Cushman, 1920)

Cycloforina rugosa (d'Orbigny, 1826)

Deuterammina celtica Brönnimann \& Whittaker, 1990

Deuterammina eddystonensis Brönnimann \& Whittaker, 1990

Deuterammina rotaliformis Heron-Allen \& Earland, 1911

Disborbis cf. D. clara Cushman, 1949

Discorbis mira Cushman, 1931

Discorbis orbicularis (Terquem, 1875)

Discorbis parkeri Natland, 1950

Discorbis villardeboanus (d'Orbigny, 1839)

Dyocibicides biserialis Cushman \& Valentine, 1929

Edentostomina sp

Eggerelloides scaber (Williamson, 1858)

Elphidium advenum (Cushman, 1922)

Elphidium articulatum (d'Orbigny, 1839)

Elphidium complanatum (d' Orbigny 1839)

Elphidium crispum (Linné, 1758)

Elphidium earlandi Cushman, 1936

Elphidium excavatum Terquem, 1875

Elphidium gerthi (van Voorthuysen, 1957)

Elphidium jenseni (Cushman, 1963)

Elphidium macellum (Fichtel \& Moll, 1798)

Elphidium oceanensis (d'Orbigny, 1826)

Elphidium spp.

Elphidium williamsoni (Haynes, 1973)

Eoeponidella nanoconica Seiglie, 1964

Epistominella vitrea Parker 1952

Eponides concameratus (Williamson, 1858)

Eponides terebra Cushman, 1933

Favulina hexagona (Williamson, 1848)

Fissurina densifasciataformis Albani \& Yassini, 1989

Fissurina globosa Bornmann, 1855

Fissurina globosocaudata Albani \& Yassini, 1989

Fissurina imporcata McCullock, 1977

Fissurina lucida (Williamson, 1848)

Fissurina marginata (Montagu, 1803)

Fissurina orbignyana Seguenza, 1862

Fissurina spp.

Fissurina submarginata (Boomgart, 1949)

Fissurina subquadrata Parr, 1945

Fursenkoina sp.

Gavelinopsis praegeri Heron-Allen \& Earland 1913

Glabratella chasteri (Heron-Allen \& Earland, 1913)

Glabratella sp.

Globobulimina auriculata (Bailey, 1851)

Globocassidulina rossensis (Kennett 1967)

Globocassidulina subglobosa (Brady, 1881)

Globulina inaequalis Reuss, 1850

Globulina myristiformis (Williamson, 1858)

Glomospira gordialis (Jones \& Parker, 1860)

Guttulina lactea (Walker \& Jacob, 1798)

Hanzawaia nitidula (Bandy, 1953)

Haplophragmoides canariensis (d'Orbigny, 1839)

Haplophragmoides manilaensis Andersen, 1953

Haplophragmoides wilberti Andersen, 1953

Haynesina germanica (Ehrenberg, 1840)

Helenina anderseni (Warren, 1957)

Jadammina macrescens (Brady, 1870)

Lachlanella undulata (d'Orbigny, 1826)

Lagena cornigera Buchner, 1940

Lagena laevis (Montagu, 1803)

Lagena perlucida (Montagu, 1803)

Lagena spiratiformis McCulloch, 1981

Lagena striata (d'Orbigny, 1839)

Lagenoselenia sp.

Lagenosolenia seguenziana (Fornasini, 1886)

Lamarckina haliotidea (Heron-Allen \& Earland, 1911)

Laryngosigma hyalascidia Loeblich \& Tappan, 1953

Laryngosigma lactea (Walker \& Jacob, 1798)

Laticarinina altocamerata (Heron-Allen \& Earland, 1922)

Lenticulina atlantica (Barker, 1960)

Lenticulina orbicularis (d'Orbigny, 1826)

Lenticulina spp.

Lepidodeuterammina ochracea (Williamson, 1858)

Leptohalysis catella (Höglund, 1947)
Lobatula lobatula (Walker \& Jacob, 1798)

Massilina secans d'Orbigny, 1826

Miliammina fusca (Brady, 1870)

Miliolinella circularis (Bornemann, 1855)

Miliolinella spp.

Miliolinella subrotunda (Montagu, 1803)

Mychostomina revertens (Rhumbler, 1906)

Neoconorbina spp.

Nonion fabum (Fichtel \& Moll, 1798)

Nonion pauperatum (Balkwill \& Wright, 1885)

Nonion spp.

Nonionella japonica var. mexicana Cushman \& McCulloch, 1940

Nonionella stella Cushman \& Moyer, 1930

Oolina alcocki (White, 1956)

Oolina caudigera (Wiesner, 1931)

Oolina sp.

Ophthalmina kilianensis Rhumbler, 1936

Palliolatella bradyformis McCulloch, 1977

Parafissurina lata (Wiesner, 1931)

Parafissurina sublata Parr, 1950

Parafissurina subovata Parr, 1950

Paratrochammina (Lepidoparatrochammina) lepida Brönnimann \& Whittaker, 1986

Paratrochammina bartrami (Hedley, Hurdle \& Burdett, 1967)

Paratrochammina wrighti Bronnimann \& Whittaker, 1983

Patellina corrugata Williamson, 1858

Pateoris hauerinoides (Rumbler, 1936)

Planorbulina mediterranensis d'Orbigny, 1826

Polysaccammina ipohalina Scott, 1976

Polysiphotrocha siphonata Seiglie, 1964

Procerolagena gracillima (Seguenza, 1862)

Pyrgo depressa (d'Orbigny, 1826)

Quinqueloculina akneriana d'Orbigny, 1847

Quinqueloculina auberiana d'Orbigny, 1839

Quinqueloculina culebriana McCulloch, 1977

Quinqueloculina laevigata d'Orbigny, 1826

Quinqueloculina lamarckiana d'Orbigny, 1839

Quinqueloculina lata Terquem, 1876

Quinqueloculina oblonga (Montagu, 1803)

Quinqueloculina poeyana d'Orbigny, 1840

Quinqueloculina seminulum (Linné, 1758)

Quinqueloculina spp.

Quinqueloculina villafranca Le Calvez, 1958

Rectuvigerina phlegeri Le Calvez, 1959

Remaneica helgolandica Rhumbler, 1938

Remaneica plicata (Terquem, 1876)

Reophax curtus Cushman, 1920

Reophax dentaliniformis (Brady 1881)

Rosalina araucana d'Orbigny, 1839

Rosalina globularis d'Orbigny, 1826

Rosalina micens (Cushman, 1933)

Rosalina millettii (Wright, 1911)

Rosalina williamsoni (Chapman \& Parr, 1932)

Rotaliammina sigmoidea Wells, 1985

Sahulia conica (d'Orbigny, 1840)

Scherochorella moniliforme (Siddall, 1886)

Septloculina tortuosa El-Nakhal, 1990

Septotrochammina gonzalezi (Seiglie, 1964)

Siphonaperta aspera (d'Orbigny, 1826)

Spirillina vivipara Ehrenberg var. runiana Heron-Allen \& Earland, 1930

Spirillina vivipara Ehrenberg, 1843

Spiroloculina excavata d'Orbigny, 1846

Spiroloculina lucida Cushman \& Todd, 1944

Spiroloculina rotundata d'Orbigny, 1826

Spiroplectinella earlandi (Parker, 1952)

Stainforthia complanata (Egger, 1895)

Stainforthia feylingi Knudsen \& Seidenkrantz, 1993

Stainforthia fusiformis (Williamson, 1858)

Stainforthia loeblichi Feyling-Hanssen, 1954

Textularia lateralis Lalicker, 1935

Textularia truncata Höglund, 1947

Tiphotrocha comprimata (Cushman \& Brönnimann, 1948)

Tiphotrocha concava Seiglie, 1964

Trifarina angulosa (Williamson, 1858)

Triloculina bermudezi Acosta, 1940

Trochammina adaperta Rhumbler, 1938

Trochammina globigeriniformis (Parker \& Jones) var. pygmaea Höglund, 1947

Trochammina haynesi (Atkinson, 1969)

Trochammina inflata (Montagu, 1808)

Valvulineria bradyana (Fornasini, 1900)

Wiesnerella auriculata (Egger, 1893) 